\title{
DEVELOPMENT OF PASSIVE ENERGY SOURCE AS EARTH AIR PIPE HEAT EXCHANGERS (EAPHE) SYSTEM -A REVIEW
}

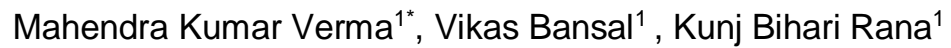

\begin{abstract}
Diversity in living standards and population growth leads to increased global energy consumption. Human comfort always plays a vital role in using different means to reduce the effects of weather conditions. The building sector captures approximately $40 \%$ of the global energy and it is most commonly used for cooling and for heating of the space occupied due to the use of appliances such as room heaters or air coolers, air conditioners, etc. The use of these appliances contributes significantly to global warming, which is a very serious environmental problem. Passive energy sources are used widely to reduce the consumption of energy due to heating and cooling of the building. Earth air pipe heat exchanger is one of the passive cooling/ heating technology used for the indoor thermal comfort of the occupants. In this review article, various discussion has been done on the use of passive energy explained by the earth air pipe heat exchanger and various investigations conducted by authors under different conditions and parameters like air velocity, pipe depth, pipe length, etc. that the thermal conductivity of the soil is the key point to the efficient operation of the earth air pipe heat exchanger system and it is also necessary to maintain the thermal conductivity of the soil in the vicinity of the pipe in order to achieve better performance in operation.
\end{abstract}

\section{Keywords: Earth Pipe Heat Exchanger, Passive Energy, Air Velocity, Pipe Length, Thermal Conductivity} of Soil.

\section{INTRODUCTON}

The thermal comfort of the current generation by conventional means, such as the HVAC system, is one of the major sources of energy consumption as it consumes about $40 \%$ of total energy [1]. This extraordinary energy consumption in the construction sector leads to energy crises and leads to a challenging environment for human beings. Moreover, it has been found that population growth results in the demand for energy in the construction sector, which is unfavourable in the current scenario. The current scenario states that consumption of energy in the construction sector is around $32-33 \%$ for space heating and cooling. [2] In order to reduce consumption of energy in the construction sector and also to reduce the size of conventional HVAC system, several techniques that use passive energy sources has to be used. It is necessary to understand the passive energy resources and their use. In fact, these passive techniques use natural energy resources with a certain amount of conventional energy to run the fan/blower to extract the air as per need. It has been found that geothermal energy is one of the most attractive as well as important passive sources/means to cool/heat the construction sector and has been used over past three decades since the 1973 oil spills [3]. Current research shows that virtually three environments are used significantly to heat or cool the building sector by exploiting geothermal energy, including (a) the earthling air pipe heat exchanger [4-6] (b) (c) GSHP $[9,10]$. In the heat exchanger of the earth pipe, ambient air is blown through the duct with the blower or blower in which the heat change process takes place due to the temperature gradient between the basement and the blowing air and this direct or indirectly is used for heating or cooling (thermal comfort) in the construction sector by season. In the second environment, the construction of the building takes place partially or totally underground [11, 12]. This process takes much more time and money due to the drainage of the soil on a large surface. In the third environment, the earth pipe heat exchanger combines with the GSHP system (ground source heat pump) consisting of buried horizontal and vertical pipes, and the extracted heat is used to heat and cool the occupied space both in both domestic as well as commercial uses [13-16] and also for snow melting on the streets and bridge surfaces during the winter season [17-18]. The fluid mainly used to work in GSHP consists of water and the antifreeze solution. By comparison, using the EAPHE is simple, reliable, cheap and economically fit according to the present scenario. The heat exchanger system of the earth pipe is mainly an arrangement of the pipe inside the soil in certain positions, with the air blowing through the pipe using the blower. Piped air changes the heat from the basement and delivers the air to the busy space. At $4 \mathrm{~m}$ depth and above, the basement temperature becomes constant; its measured value is equal to the average 
temperature of the earth surface [19,20]. Furthermore, the steady temperature of the basement is lower than the summer temperature, and the case is reversed for the winter season [21], and this temperature gradient is used for thermal comfort as per requirement. Many researchers performed investigations and experiments in the field of EAPHE under various aspects to enhance the popularity and usage of the technology in order to conserve the environment. Recently various notable reviews has been published which mainly focusses on the characteristics of the design of EAPHE system and suggestion made to combine the system with the conventional AC system [22, 23, 24]. Kaushal [25] represented various mathematical algorithm used by various researchers for EAPHE system performance and discussed it analytically as well as experimentally. Thermal performance and heat transfer also studied using corrugated tube and results shows heat transfer rate increases with Reynolds number, maximum heat transfer corresponds to corrugated tube comparison with smooth tube [26]. Orhan K et. al. carried CFD analysis of thermos hydraulic performance using tube fitted with stepped conical nozzle. Results shows overall enhancement in hydraulic performance of $11 \%$ was achieved for $\mathrm{Re}=6000$ where the spacing and step ratios are 4,2 respectively [27].

The main objective of this review paper is to understand current progress and awareness of the passive use of energy in various aspects, in particular the EAPHE system. The full review paper attempts to focus on the current technology, the current EAPHE scenario, and the fundamental physics that impacts the performance of the proposed system. This analysis also attempts to enhance performance of EAPHE's system.

\section{MATERIAL AND METHODS}

The study demonstrates significant approach to use of passive energy to ensure thermal comfort in the occupied space. All the necessary literature has been analysed in order to analyse the different work and implementation of the EAPHE system. The entire review article has been structured to cover all researches in the field of earth air pipe heat exchanger (EAPHE). The article covers all aspects of EAPHE, which includes: (a) various impacts (b) geometric analysis of EAPHE and its significance; (c) the thermal performance of EAPHE; (d) various design parameters and its impact on the performance of EAPHE system; (e) EAPHE system with practical applications. All aspects of the system were analysed using different data from the research work and appropriate discussions were conducted on it with significant conclusions and recommendations.

\section{THERMAL PERFORMANCE OF EAPHE SYSTEM}

Many researches show that using geothermal energy for thermal comfort is not a new implementation or concept. Islamic and Persian architecture has existed for centuries [28] and have been repeatedly used to obtain thermal comfort in the architectures designed by them. The first scientific approach to the EAPHE physical system started at Forman Christian College, Lahore, Pakistan. [29] Later, the EAPHE system was used at the Clara Bareilly Swine Hospital (UP), India to improve the performance of the air conditioning system and therefore showed that the system works positively to increase performance by using ambient air from EAPHE system. In addition, the EAPHE system was investigated in a nearby hospital of Delhi, India [30, 31]. The system has been installed for thermal comfort both in the complex areas as well as in the residential areas. The arrangement consists of an 80 metre long pipe with a cross-section of $0.528 \mathrm{~m}^{2}$ and as a result a cooling capacity of around $512 \mathrm{kWh}$ as well as a seating capacity of 269 $\mathrm{kWh}$ with a velocity of air, $4.89 \mathrm{~m} / \mathrm{sec}$. From the result, it was concluded that the heating capacity was not adequate according to the requirements during the winter season. Later, various discussions were discussed about the limitation of the EAPHE system. Akridge [32] has successfully analysed the limitations of the use of passive energy. In the humid region, the EAPHE system may be effective to achieve a sensitive cooling, and latent cooling does not work efficiently. It has been disclosed by Bansal et al. [33] that the efficiency of EAPHE depends entirely on the state of the surface and subsoil. For example, it has been assumed that wetting the surface by various means can increase thermal comfort during the summer season. Mihalakalau et al. [34] investigated the potential of EAPHE in the Greek climate. They evaluated the thermal performance of the system by using the arrangement consisting of a plastic pipe of radius 0.125 meters and a length of 30 meters with a depth of 1.2 meters inside the terrain. The air was blown at a speed of $5 \mathrm{~m} / \mathrm{sec}$. The analysis was conducted for June, July and August. The output showed that the air temperature fluctuated from 0.7 to $23.7{ }^{\circ} \mathrm{C}$ for June, 23.3 to $27{ }^{\circ} \mathrm{C}$ for July and $5.1-28.5^{\circ} \mathrm{C}$ for the month of August, respectively for the inlet air temperature of 0.9 to $37^{\circ} \mathrm{C}$ in June, 23.2 to $40^{\circ} \mathrm{C}$ in July, and 5.3 to $39.3^{\circ} \mathrm{C}$. Zhang et al. [35] and Ishihara et al. [36] observed a positive result after implementing the EAPHE system in the Kumamoto test house to reduce the indoor temperature by $1{ }^{\circ} \mathrm{C}$. Furthermore, Thanu et al. [37] investigated on the thermal performance of the EAPHE system from a past and past to the recently-built Gulmohar farmhouse in Gurgaon India. In addition, Kumar et al. [38] analysed the potential of energy conservation of the EAPHE system in which they proposed a system with 
a pipe of $80 \mathrm{~m}$ long and a cross-sectional area of $0.53 \mathrm{~m}^{2}$ where $19 \mathrm{~kW}$ power is used for air velocity $4.9 \mathrm{~m} / \mathrm{s}$. As a result, the room temperature remained at about $7.63{ }^{\circ} \mathrm{C}$ in the Indian climate. Chel and Tiwari [39] determined the thermal potential of the EAPHE system in which it integrated the adobe IIT Delhi house. EAPHE system was built with a PVC pipe of $6 \mathrm{~cm}$ diameter buried at a depth -1.5 meters. $0.3 \mathrm{~kW}$ air blowers were used to blow air inside the pipe. The analysis leads to significant cooling of the connected system. Al Azmi et al. [40] have developed a theoretical model in order to investigate the energy conservation potential of the EAPHE system in Kuwait's desert climate. It has been reported that the cooling demand reduction is about 30\% in the peak season (mid-July). Bojiec et al. [41] investigated the thermal behaviour potential of an EAPHE system used for cooling or heating the building. Within the system, $100 \%$ pure air is used as a heating or cooling medium for EAPHE. The system consists of $140 \mathrm{~mm}$ diameter circular steel tubes. The complete system has two parallel pipes of 50 meters in length, each buried 2.1 meters below the ground. The system could reduce consumption of energy because of the thermal comfort of the building. Experimental analysis by Nadia et al. [42] used 60 meter long pipe to investigate the thermal performance of the EAPHE in Ouargla, Southeast of Algeria. To achieve the desired effect, the pipe is maintained between 40 and 45 meters, and in the case of a length of fewer than 40 meters, the system cannot reduce the temperature near the ground temperature. It was recommended to maintain the speed of about $2 \mathrm{~m} / \mathrm{sec}$. Recently Yang et al. investigated the decrease of the temperature on the length of the buried pipe and it was found that for a pipe of 200 meters length, the temperature drop was $5{ }^{\circ} \mathrm{C}$ for the summer season. Mishra et al., [72] studied the impact of transient analysis and thermal conductivity of soil on the continuous operation of EAPHE system. It was reported that steady-state analysis recorded an increase of $19.6^{\circ} \mathrm{C}$ with a 60 meter length pipe of diameter arrangement of 0.1 meters at a speed of $5 \mathrm{~m}$ / s. While in case of analysis the temperature is reduced from 19.6 to $17.2^{\circ} \mathrm{C}$ as a result of a continuous operation of the EAPHE 24-hour system with a thermal conductivity of $0.52 \mathrm{Wm}^{-1} \mathrm{~K}^{-1}$. After twenty four hours of operation, temperature was reduced from 19.6 to $19.2^{\circ} \mathrm{C}$ and also from 19.6 to $19.5^{\circ} \mathrm{C}$ with thermal conductivity of soil being $2.0 \mathrm{Wm}^{-1} \mathrm{~K}^{-1}$ and $4.0 \mathrm{Wm}^{-1} \mathrm{~K}^{-1}$. From the output, it was found that for the efficient efficiency of the EAPHE system it is necessary to regenerate the thermal potential of the soil. All the above discussions shows that the performance variation of the EAPHE system is due to climate change, soil thermal properties, the geometric configuration of the system and many other factors. It has been observed in some cases that the climatic condition is largely responsible for the overall performance of the system. In some cases, the small length of the pipe ensures adequate thermal comfort, while for some cases it requires a long pipe. The total thermal performance of the system requires a lot of attention and study needs to be done on the various factors related to it.

\section{SUBSOIL TEMPERATURE AND IMPACT OF SURFACE PROPERTIES}

The subsoil temperature is mainly a key factor for the effectiveness of the EAPHE system hence few researchers mainly focused on the experimental analysis of the same [44, 46, 47, and 68]. Some of them investigated analytically using various empirical models [50-52]. It is a fact that thermal behaviour of the earth surface mainly influences the subsoil thermal performance and its temperature varies with respect to season, area and the climatic condition of the particular region.

$$
-\left.K \frac{\delta T \text { surf }}{\delta y}\right|_{y=0}=\mathrm{h}_{\text {sur }}\left[T_{c t}-T_{\text {sur }}\right]+\alpha_{0} S-m-c \Delta R
$$

The first term on RHS of the above equation represents the heat flux as a result of transfer of heat between air and the surface, the 2nd term represents the solar energy which is absorbed by the surface, the 3rd term represents the heat flux as a result of evaporation of water from the surface of the body and the last term represents the net longwave radiation exchange between the sky and the surface (Its value is usually $61.5 \mathrm{~W} / \mathrm{m}^{2 \circ} \mathrm{C}$ for all types of surfaces) [47]. Mihalakakou et al. [54] investigated the energy balance equation with respect to earth surface and its impact on the temperature distribution of the soil. The investigation concluded that thermo-physical properties of the surface affect the temperature of the subsoil. Derbel and Kanoun [3] performed an investigation of the properties of the soil such as density, thermal conductivity and specific heat and also correlated the impact on the subsoil temperature at various depths. The current study concludes that small depth had a negligible effect on the subsoil temperature which is less than $1^{\circ} \mathrm{C}$.

In order to investigate the subsoil temperature with respect to the depth various experimental and numerical studies were performed $[8,20,44,46,47,48,49,50,51,52,53,54,55,56,57,58,59,60]$. Some of the studies investigated 
about the impact of daily as well as annual changes in the surface temperature on the depth of the subsoil temperature and it was observed that penetration of the surface temperature variation on daily basis is about $0.5 \mathrm{~m}$ only while in case of annual basis it is about $4 \mathrm{~m}$. [53, 61-63]. The temperature variation noted was about $7-8^{\circ} \mathrm{C}$ in $\mathrm{Bangkok}$ for about 1-meter depth throughout the year [65].

Table 1. Distribution of temperature under the ground (a) [43], (b) [44], (c) [45], (d) [46].

(a) Jinghai, Tianjin

\begin{tabular}{|l|l|l|l|l|}
\hline $\begin{array}{l}\text { Depth } \\
(\mathrm{m})\end{array}$ & \multicolumn{4}{|c|}{ Temperature $\left({ }^{\circ} \mathrm{C}\right)$} \\
\hline & March & December & June & September \\
\hline 3 & 6.30123 & 11.0427 & 18.1998 & 22.9415 \\
\hline 5 & 8.57706 & 12.6484 & 16.5435 & 20.7887 \\
\hline 10 & 12.2426 & 13.7485 & 14.952 & 16.7351 \\
\hline 15 & 13.6771 & 14.3012 & 14.8003 & 15.2815 \\
\hline 20 & 14.2564 & 14.6397 & 14.8358 & 14.9605 \\
\hline 25 & 14.4931 & 14.6446 & 14.4931 & 14.6446 \\
\hline 30 & 14.3961 & 14.3961 & 14.3961 & 14.3961 \\
\hline 35 & 14.0944 & 14.0944 & 14.0944 & 14.0944 \\
\hline 40 & 14.0857 & 14.0857 & 14.0857 & 14.0857 \\
\hline 45 & 14.2428 & 14.2428 & 14.2428 & 14.2428 \\
\hline 50 & 14.0201 & 14.0201 & 14.0201 & 14.0201 \\
\hline
\end{tabular}

(b) Poznan

\begin{tabular}{|l|l|l|l|l|l|l|}
\hline Depth $(\mathrm{m})$ & \multicolumn{7}{|c|}{ Temperature $\left({ }^{\circ} \mathrm{C}\right)$ By date } \\
\hline & 15.11 .19 & 10.10 .99 & 23.08 .99 & 2.07 .99 & 28.07 .99 & 20.09 .99 \\
\hline 0 & 0.478036 & 9.97416 & 19.522 & 26.447 & 29.0568 & 29.845 \\
\hline 0.05 & 1.57623 & 9.66408 & 19.509 & 23.1783 & 25.7364 & 29.1731 \\
\hline 0.1 & 1.97674 & 9.17313 & 19.2636 & 21.8605 & 24.5866 & 28.6951 \\
\hline 0.2 & 3.46253 & 8.60465 & 18.1912 & 18.9793 & 23.3592 & 24.0181 \\
\hline 0.35 & 4.70284 & 9.40568 & 18.5271 & 18.3204 & 21.3307 & 21.3824 \\
\hline 0.5 & 6.60207 & 11.3824 & 19.4186 & 19.1344 & 19.9483 & 19.9096 \\
\hline 0.75 & 9.57364 & 13.6822 & 20.7106 & 19.2377 & 18.7468 & 18.7984 \\
\hline 1 & 10.5943 & 14.9096 & 20.6977 & 19.2765 & 18.0233 & 18.1654 \\
\hline 1.2 & 11.6537 & 15.5556 & 20.4005 & 19.1344 & 17.1705 & 17.2481 \\
\hline 1.5 & 12.3514 & 16.0594 & 20.0517 & 19.2377 & 16.9767 & 16.9767 \\
\hline 2 & 13.6176 & 16.9767 & 18.9664 & 18.6047 & 15.0258 & 14.9871 \\
\hline 2.5 & 14.5736 & 17.1576 & 18.0749 & 17.8036 & 14.0052 & 13.9276 \\
\hline 3 & 15.0129 & 16.8605 & 16.7829 & 17.704 & 12.9457 & 12.9457 \\
\hline
\end{tabular}

(c) India

\begin{tabular}{|c|c|c|c|c|}
\hline Time & \multicolumn{4}{|c|}{ Temperature $\left({ }^{0} \mathrm{C}\right)$} \\
\hline & Srinagar & Delhi & Chennai & Jodhpur \\
\hline 1 & 11.2751 & 30.8234 & 34.3525 & 36.7373 \\
\hline 2 & 10.7722 & 30.8626 & 34.3916 & 36.7766 \\
\hline 3 & 9.88417 & 30.7572 & 34.2502 & 36.7194 \\
\hline 4 & 9.26063 & 30.4471 & 34.0001 & 36.5054 \\
\hline
\end{tabular}

\begin{tabular}{|r|r|r|r|r|}
\hline 5 & 8.80617 & 29.9926 & 33.7022 & 36.3039 \\
\hline 6 & 8.88138 & 29.8269 & 33.368 & 36.1743 \\
\hline 7 & 9.40219 & 29.7578 & 33.2988 & 36.0088 \\
\hline 8 & 10.104 & 29.7606 & 33.3378 & 35.9876 \\
\hline 9 & 10.7814 & 30.0167 & 33.5337 & 36.0268 \\
\hline 10 & 11.266 & 30.2001 & 33.7053 & 36.1262 \\
\hline 11 & 11.5222 & 30.4563 & 33.9974 & 36.2737 \\
\hline 12 & 11.5372 & 30.6641 & 34.193 & 36.4334 \\
\hline 13 & 11.167 & 30.7272 & 34.2563 & 36.5809 \\
\hline
\end{tabular}


(d) Nicosia, Cyprus

\begin{tabular}{|r|r|r|}
\hline \multicolumn{1}{|l|}{$\begin{array}{l}\text { Depth (m) } \\
\text { in ground }\end{array}$} & \multicolumn{2}{|c|}{ Temperature $\left({ }^{\circ} \mathrm{C}\right)$} \\
\hline & 25-Jan-05 & 20-Aug-05 \\
\hline 0 & 7.44413 & 23.2989 \\
\hline 0.15 & 9.49188 & 26.7221 \\
\hline 0.25 & 10.8672 & 30.191 \\
\hline 0.5 & 12.1662 & 31.0468 \\
\hline 0.7 & 13.6256 & 30.0229 \\
\hline 1 & 15.3372 & 28.6552 \\
\hline 1.5 & 17.2168 & 26.7603 \\
\hline
\end{tabular}

\begin{tabular}{|r|r|r|}
\hline 2 & 18.0649 & 25.2627 \\
\hline 3 & 20.9838 & 23.6734 \\
\hline 5 & 22.8787 & 23.1385 \\
\hline 10 & 21.916 & 23.0315 \\
\hline 12 & 21.5721 & 23.5511 \\
\hline 15 & 21.511 & 24.4756 \\
\hline 18 & 21.7326 & 22.9093 \\
\hline 21 & 21.5874 & 22.9933 \\
\hline 30 & 20.3954 & 20.2732 \\
\hline 40 & 21.0602 & 20.6934 \\
\hline 50 & 21.2818 & 20.9685 \\
\hline
\end{tabular}

In Guangzhou, South China, the monthly average temperature variation was investigated by Wen et.al [21] and it was verified that the gradual variation of the basement temperature increased with increase in depth. Popiel et al. [44] investigated the temperature measurement of the car parking area and a lawn in Poznan for depth variation, i.e. 0-2 meters and 0-17 meters. As a result, it was found that at the parking area of the vehicle, the temperature is $1{ }^{\circ} \mathrm{C}$ greater than the surface of the lawn (with short grass). Various researcher shows the earth temperature at different depth and at different time during the year, table 1 shows the relationship between the temperature and the depth of the ground for different locations, it shows the temperature of the soil remains constant at certain depth as per the location and geographic conditions.

It is necessary to optimize the basement temperature between $\left(18-30^{\circ} \mathrm{C}\right)$ to be used for the thermal comfort of the occupied space. Different manipulations performed in terms of the above equation can help modify the basement and surface temperature in order to enhance the performance of the proposed system. It has been analysed that many implementations vary depending on climatic conditions. Bansal et al. [61] has made various estimates based on the surface area of the earth with various materials for the 4-meter depth in Delhi, India for different climatic conditions. As a result, it was shown that the maximum temperature was $53^{\circ} \mathrm{C}$ for the covered black surface and $17.3^{\circ} \mathrm{C}$ for the area covered by various plants, shrubs, etc. Ghoshal et al. conducted a study to analyse subsurface temperature variation in two places for the greenhouse and others for the bare surface in Delhi. The daily and monthly study determined that the underground temperature at different depths under the greenhouse was about $7-9^{\circ} \mathrm{C}$ and in comparison with the bare surface it was about 3 to $6^{\circ} \mathrm{C}$ higher for the daily and the monthly variation of the basement temperature. Some researchers have suggested that the earth is covered with small stones (pebbles), shedding, wetting or lime coating to reduce the basement temperature $[56,66,67]$.B. Givoni conducted an experiment at the Institute for Disease Research in Israel and concluded that the irrigated soil covered with pebbles thickness $12 \mathrm{~cm}$ decreases the temperature by $9^{\circ} \mathrm{C}$ to the undisturbed area. While covering the surface of the earth with dark sheets leads to the rise of the basement temperature. [7] Recently, some experiments were performed by Nassar et al. [68] in Tripoli, Libya, where the underground temperature measurement was analysed at a depth of 4-meter with bare ground and covered with dry glass. It was found that during December and January the maximum temperature was $1.5^{\circ} \mathrm{C}$ and $47^{\circ} \mathrm{C}$ respectively, and the minimum temperature was observed in May and June, that is $19^{\circ} \mathrm{C}$ and $44^{\circ} \mathrm{C}$, respectively.

Impact on subterranean temperature due to EAPHE pipe: Sodha et al. [69] made the calculation of the outlet air of the pipeline taking both the surface of the cylindrical tunnel and the surface of the undisturbed earth in which the temperature was equal, which leads to an infinite thermal conductivity and a limited capacity of the earth around the tunnel. Practically, the impact of tube/tube presence affects the temperature variation of the basement, which affects the thermal potential behaviour of the EAPHE system. Depending on the pipe or tube usage, the convective heat transfer takes place between the inner surface of the pipe and moving air due to the thermal gradient between them. And the transfer of conductive heat between the surrounding basement and the inner surface of the tube/pipe that is responsible for changing the underground temperature and it is necessary to investigate the possible means to increase the thermal performance of the EAPHE. The geometric configuration of the EAPHE system was defined by the dimensional parameter $\left(\mathrm{U}^{*}\right)$. 
The equation for relation of the geometrical parameter is as follows:

$$
\frac{1}{U^{*}}=\frac{2 \pi R_{i p} h_{i} \ln \left[\frac{Z}{R_{O p}}+\sqrt{\left(\frac{Z}{R_{O p}}\right)^{2}-1}\right\rceil}{2 \pi k_{g}}+\frac{2 \pi R_{i p} R_{i p} h_{i} \ln \frac{R_{O p}}{R_{i p}}}{2 \pi k_{p}}
$$

In the above equation;

$k_{p=}$ Pipe material thermal conductivity

$R_{o p=}$ Outer radius of the buried pipe.

$R_{i p=}$ Inner radius of the buried pipe.

$h_{i=}$ Heat transfer coefficient due to convection of the inner surface of buried pipe.

In the above equation, the first right-hand term emphasizes the ratio of conductive thermal resistance it possesses from ground or the subsoil to the heat flow beyond it and the conductive thermal resistance possessed by the flow of air to the inner surface of the pipe / tube buried. The value of the second term is much lower compared to the first term and can be neglected.

For an efficient recovery performance by EAPHE, soil and its thermal saturation plays an important role and needs to be investigated significantly. In addition, both the factors can be improved or influenced by a defined operation, which may be continuous or periodic. Recently, Mathur et al. [70] investigated the above two factors for efficient performance, namely thermal saturation and soil recovery around the buried pipeline for continuous and intermittent modes of operation. As a result, soil temperature has been recovered in both ways by adopting the natural heat conductivity (heat extracted from the near-neighbour pipe) and convection (the heat removed from the underground by night air purging). The complete experiment was performed on a $5 \mathrm{~m}$ long pipe for intermittent and continuous mode for a running time of 1.30, 45.60 days and as a conclusion it was shown that the heat penetration was more in the basement intermittently compared to the module continuously, while the continuous heat recovery mode works efficiently than the intermittent mode.

For efficient EAPHE performance, it is desirable to evaluate the basement temperature. To increase the effectiveness of the EAPHE system, it must adopt an appropriate strategy to increase the effectiveness of the basement. In some reviews, it was estimated that various factors play a key role in surface temperature recovery. Air speed, ambient air temperature and climate condition are largely responsible for improving system performance. Various research has also estimated that the system arrangement includes pipe position, size and pitch between two pipes fluctuating significantly in performance.

\section{IMPACT OF DESIGN PARAMETERS ON EAPHE SYSTEM}

Influence of different parameters on the geometry of the EAPHE system results in a variation in system performance. For example, pipe geometry including: pipe length, pipe diameter, operational parameters including air velocity, air pressure, etc. the pipes, etc.

\section{Influence of pipe parameter on the performance of EAPHE system.}

For an efficient performance of an EAPHE, different parameters, such as pipe diameter, pipe length and material properties, and depth of buried pipe are responsible. Recently, many researches were conducted according to the parametric variation to investigate the impact significantly in different arrangements [83,92]. Rakesh et al. [64] studied about the behaviour of various factors influencing air outlet temperature, including air velocity, pipe diameter, pipe length and depth of the pipe in the basement. Last F. Niu et al. [114] conducted a parametric analysis study of the EAPHE system to investigate exit temperature, humidity, etc. and also developed a regression model to perform in various operating conditions in order to analyse the required performance.

Influence of velocity of the air in buried pipe

Various research conducted by Mihalakakou et al. [4, 71, 72] reported the influence of velocity of air on the performance of the EAPHE system to ensure thermal comfort. In their investigations, they analysed the fact that 
the small variation in air velocity resulted in a notable change in the evaporative temperature of the EAPHE system. It has also been reported that increasing the air velocity reduces the heating capacity of the system. Kumar et al., [73] investigated the system by changing the air flow rate from $2.58 \mathrm{~kg} / \mathrm{sec}$ to $1.2 \mathrm{~kg} / \mathrm{sec}$, resulting in room temperature changes from $7.65^{\circ} \mathrm{C}$ to $50.9^{\circ} \mathrm{C}$. Sodha et al. observed that there is an increase in air velocity with the decrease in tunnel length. It has been reported that increasing the rate of air velocity results in a low-temperature gradient between the inlet air and the exhaust air of the system [74]. Serageldin et al. [75] studied in the Egyptian climate that increasing fluid velocity from $1-3 \mathrm{~m} / \mathrm{s}$ results in an increase in temperature from $0.4{ }^{\circ} \mathrm{C}$ to $19.4{ }^{\circ} \mathrm{C}$. The data in table 5 depicts the effect of air velocity on the efficiency, COP temperature and system output. The graph concludes that all three parameters decrease with increasing air velocity inside the buried pipe.

\section{Effect of Pipe Material}

Various EAPHE research has been performed using different pipe materials. Santamauris et al., [76] reported the analysis using various pipe materials, such as plastic, aluminium, concrete and cast. Bojie et al., [77]

Table 2. Depicts the Variation in outlet temperature of EAPHE with respect to pipe material

\begin{tabular}{|l|l|l|l|l|}
\hline $\begin{array}{l}\text { Materi } \\
\text { al of } \\
\text { pipe }\end{array}$ & $\Delta T\left(\right.$ in $^{\circ} \mathrm{l}$ Effec & $\begin{array}{l}\text { Air } \\
\mathrm{t} \\
\text { velocity }(\mathrm{m} \\
/ \mathrm{s})\end{array}$ & $\begin{array}{l}\text { referenc } \\
\mathrm{e}\end{array}$ \\
\hline PVC & 4.5 & rise & 2 & {$[76]$} \\
\hline PVC & 2.6 & rise & 2 & {$[73]$} \\
\hline Steel & 4.8 & rise & 2 & {$[76]$} \\
\hline Steel & 2.7 & rise & 2 & {$[73]$} \\
\hline Copper & 2.7 & rise & 2 & {$[73]$} \\
\hline PVC & 10.3 & drop & 2 & {$[103]$} \\
\hline Steel & 12.7 & drop & 2 & {$[103]$} \\
\hline
\end{tabular}

Table 3. Compares the temperature variation using steel and PVC pipe for the system

\begin{tabular}{|l|l|l|l|}
\hline $\begin{array}{l}\text { Pipe } \\
\text { material }\end{array}$ & $\begin{array}{l}\text { Material } \\
\text { conductivity } \\
\left(\mathrm{Wm}^{-1} \mathrm{~K}^{-1}\right)\end{array}$ & $\begin{array}{l}\text { Cooling } \\
\text { potential } \\
(\mathrm{kWh} / \text { year })\end{array}$ & $\begin{array}{l}\text { Heating } \\
\text { potential } \\
(\mathrm{kWh} / \text { year })\end{array}$ \\
\hline plastic & 0.24 & 933.96 & 388.81 \\
\hline steel & 57 & 939.89 & 391.25 \\
\hline copper & 395 & 939.92 & 391.27 \\
\hline
\end{tabular}

Selected PVC and steel for their investigation and showed that the material has no effect on the thermal behaviour of the EAPHE system. Table 2 shows the variation of the outlet temperature of EAPHE with regard to pipe material and shows that there are no high-temperature variations. Table 3 compares the temperature variation using steel and PVC pipe for the system. Effect of material properties and parameters on the thermal performance of the EAPHE was analysed by Viorel Badeseu [81].

\section{Effect of depth of pipe in subsoil}

Investigations were carried out by Derbel and Kanoun [55] in order to analyse the efficiency of the system at various depth of the pipe inside the earth. It was also revealed that inside air temperature of the pipe decreases with increase in depth of the pipe up to certain limit.[82] Wu et al. [21] investigated the effectiveness of the EAPHE system at various depths of buried pipe. As a result, variation in temperature of air was found to be between $7.2{ }^{\circ} \mathrm{C}-31.7^{\circ} \mathrm{C}$ and between $5.7^{\circ} \mathrm{C}$ to $30.7^{\circ} \mathrm{C}$ at a depth of $1.6 \mathrm{~m}$ and $3.2 \mathrm{~m}$ of the pipe. Badescu [81] investigated that depth of the buried pipe increases the thermal potential of the system but limiting up to 4 meters only.

\section{Effect of spacing between the tubes/pipes}

Various experimental analysis suggested that single pipe with short length could not provide adequate thermal comfort. One of the investigations reported that use of four parallel pipes instead of two pipes of less than 17 $\mathrm{m}$ is more effective than single pipe. Sodha et al. [84] concluded the results of spacing between the pipes. In their conclusion it was addressed that heating potential increases with the increase in spacing and it starts decreasing in case of cooling. Hence it was suggested to keep small spacing between the pipes for effective heating potential. Yoon et al. [85] explained the effect of interval of pipe on the heat transfer rate. Investigation shows that result were independent from pipe diameter. Reduction of the spacing to $1 \mathrm{~m}$ resulted in 15 to $25 \%$ loss of power. 
Table 4. Variation of mean efficiency, Coefficient of performance with respect to pipe length of EAPHE. (1) [79], (II) [80].

(I)

\begin{tabular}{|l|l|l|}
\hline $\begin{array}{l}\text { Pipe length } \\
(\mathrm{m})\end{array}$ & $\begin{array}{l}\text { Mean } \\
\text { Efficiency }\end{array}$ & COP \\
\hline 10.2186 & 0.237291 & 0.196012 \\
\hline 20.7929 & 0.376154 & 0.243135 \\
\hline 29.9726 & 0.480923 & 0.272116 \\
\hline 40.3874 & 0.582141 & 0.283988 \\
\hline 50.2366 & 0.656722 & 0.286667 \\
\hline 60.2655 & 0.725266 & 0.28417 \\
\hline 70.285 & 0.777829 & 0.276621 \\
\hline 80.3443 & 0.820091 & 0.268889 \\
\hline 90.536 & 0.853831 & 0.259391 \\
\hline 100.357 & 0.880822 & 0.248919 \\
\hline
\end{tabular}

(II)

\begin{tabular}{|l|l|l|}
\hline $\begin{array}{l}\text { Pipe } \\
\text { length } \\
(\mathrm{m})\end{array}$ & $\begin{array}{l}\text { Mean } \\
\text { Efficiency }\end{array}$ & $\begin{array}{l}\text { Daily } \\
\text { cooling } \\
\text { potential }\end{array}$ \\
\hline 5.08578 & 12.8626 & 216.114 \\
\hline 10.335 & 54.1872 & 973.46 \\
\hline 15.0531 & 76.0263 & 1348.82 \\
\hline 19.9755 & 87.1921 & 1551.66 \\
\hline 25.0613 & 93.2129 & 1654.98 \\
\hline 30.1062 & 96.4423 & 1707.11 \\
\hline 35.0694 & 98.0843 & 1741.23 \\
\hline 39.9714 & 98.96 & 1753.55 \\
\hline 45.0368 & 99.0695 & 1757.35 \\
\hline
\end{tabular}

Table 5. Air velocity effect on COP, efficiency outlet temperature of the EAPHE system [63, 102]

\begin{tabular}{|l|l|l|}
\hline $\begin{array}{l}\text { Air } \\
\text { velocity } \\
(\mathrm{m} / \mathrm{s})\end{array}$ & $\begin{array}{l}\text { Mean } \\
\text { Efficiency }\end{array}$ & COP \\
\hline 1 & 2.41494 & 0.784454 \\
\hline 2 & 0.551867 & 0.659193 \\
\hline 3 & 0.099585 & 0.563528 \\
\hline 4 & 0.035961 & 0.481315 \\
\hline 5 & 0.009682 & 0.424215 \\
\hline 6 & 0.004149 & 0.392825 \\
\hline 7 & 0.011065 & 0.352765 \\
\hline 8 & 0.006916 & 0.324963 \\
\hline 9 & 0.011065 & 0.301345 \\
\hline 10 & 0.012448 & 0.279223 \\
\hline
\end{tabular}

Table 6. Variation in tunnel performance parameters with respect to radius of the tunnel [90]

\begin{tabular}{|l|l|l|l|l|l|l|l|l|}
\hline \multicolumn{5}{|c|}{ Dry- sunlit } & \multicolumn{4}{c|}{ Wet shaded } \\
\hline $\mathrm{R}(\mathrm{cm})$ & $H_{p}(M W h)$ & $(L)_{\text {opt }(m)}$ & $C_{p}(M W h)$ & $(L)_{\text {opt }(m)}$ & $H_{p}(M W h)$ & $(L)_{\text {opt }(m)}$ & $C_{p}(M W h)$ & $(L)_{\text {opt }(m)}$ \\
\hline 2.54 & 2.1 & 104 & 0.06 & 13 & 0.22 & 45 & 2.2 & 104 \\
\hline 5.08 & 3.2 & 100 & 0.36 & 53 & 0.53 & 66 & 3.5 & 100 \\
\hline 8.90 & 3.7 & 76 & 0.56 & 49 & 0.73 & 58 & 4.2 & 84 \\
\hline 12.70 & 4.2 & 64 & 0.65 & 41 & 0.79 & 48 & 4.5 & 64 \\
\hline 25.40 & 4.3 & 31 & 0.77 & 26 & 0.88 & 29 & 4.9 & 33 \\
\hline 50.80 & 4.7 & 21 & 0.89 & 16 & 1.00 & 17 & 5.2 & 33 \\
\hline 88.90 & 4.7 & 14 & 0.98 & 10 & 1.00 & 15 & 2.0 & 13 \\
\hline
\end{tabular}

\section{Effect of pipe length}

At certain depths, the basement temperature remains constant and the temperature is high in the winter season and low in the summer season. Lee KH et al., [112] noticed that the air temperature of the EAPHE system drops during the summer and increases in the winter season with the increase of the length of the pipeline. However, the performance rate varies depending on climatic conditions and location. In the experiments it was reported that for the length of the 50 meter pipeline, the outlet temperature of the EAPHE system remains equal to the basement temperature. [106] In recent research, Derbel and Kanoun [81] investigated the energy load of the EAPHE system and reported that the load of the system depends on the pipe length and in this case the variation in length of the buried pipes from 10 meters to 30 meters 
increases the load Consequently. It has been increased due to the air time inside the buried pipe, which requires a long period of time for the heat exchange process. Basically, it was noticed that there was no effect on the air temperature for a pipe length of 5 meters. [106] various investigators have noticed that increasing the length of the pipe is responsible for the high temperature difference between intake and ventilation air. $[4,72,86]$ Mihalakakou reported a high heat capacity of the EAPHE system during the length of the pipeline from 30 meters to 70 meters. Recent research by Serageldin et al. [75] observed that the increase in length of pipe from 5.45 meters to 7.0 meters results in temperature rise from $19.7^{\circ} \mathrm{C}$ to $19.9^{\circ} \mathrm{C} . \mathrm{Wu}$ et al. [21] conducted analysis for three variations of pipe lengths in Guangzhou, southern China. Based on the results, they observed the exit temperature in between $6.1-33.6{ }^{\circ} \mathrm{C} 4.7-31.2^{\circ} \mathrm{C}$ and $3.8-29.5^{\circ} \mathrm{C}$ for the length of 20 meters, 40 meters and 60 meters when the inlet temperature varied from $7.4^{\circ} \mathrm{C}$ to $36^{\circ} \mathrm{C}$. Ahmad et al. [87] in their investigation found that length of pipe is the most important parameter of EAPHE systems. Table 4 , shows the variation in mean efficiency and COP of the system with the length of the pipe. It also shows that the performance of EAPHE increases with length of pipe and saturates after $50 \mathrm{~m}$ length. Table 5 shows the variation in mean efficiency and COP of the system with respect to the velocity of air.

\section{Effect of pipe's radius}

Many researchers have investigated the fact that the radius of the EAPHE pipe system significantly influences the performance of the system [14, 72, 71, 73, 81, 82, 37]. Increasing in the inside diameter of the buried pipe reduces the coefficient of convective heat transfer which results in high temperatures during the summer season [4] and low temperature during the winter season [72]. Mihalakakou et al. [71] performed a survey to verify the effect of the pipe diameter on the EAPHE exhaust air temperature. Their study showed that reducing the inside diameter of the pipe from 0.50 to 0.25 meters results in the exhaust air temperature increasing from $4.5^{\circ} \mathrm{C}$ to $1.5^{\circ} \mathrm{C}$. In the later study, it was discovered that lowering the radius of pipe from $150 \mathrm{~mm}$ to $100 \mathrm{~mm}$ resulted in an increase in the outlet temperature from 1.9 to $1.8^{\circ} \mathrm{C}$ in the winter season. While Kabahnikov analysed only a small temperature difference after changing the pipe diameter from 0.1 to 0.4 meters. Serageldin et al., [75] reported an increase of temperature from $0.4^{\circ} \mathrm{C}$ to $18.7^{\circ} \mathrm{C}$, with pipe diameters increasing from 0.0508 meters to 0.0762 meters. Rakesh et al. [73] reported the thermal potential of the tunnel with variation in diameter. In their investigation, they analysed the temperature increase of the occupied space (room) of $1.5^{\circ} \mathrm{C}$ with the increase of the tunnel radius. Investigation by Sodha et al. [88] showed experimentally that increase of tunnel width decreases system cooling load (tunnel geometry changed from $105 \times 0.5$ meters to $40 \times 0.2$ meters). Table 6 shoes the variation in performance of system with respect to the tunnel radius.

\section{Air pressure drop inside the pipe}

Drop of pressure is an important factor for assessing the performance of EAPHE system. Pressure drop in EAPHE system was investigated by Paepe and Janssens [87] in which they developed a relation between pressure drop and the parameters of the EAPHE system. The relation is as follows:

$$
\Delta P=\xi \frac{L}{D} \rho \frac{v_{a i r}^{2}}{2}
$$

$$
\text { Where } \xi=\frac{64}{R_{e}} \text { if } R_{e}<2300 \xi=\left(1.82 \log R_{e}-1.64\right)^{-2} \text { if } R_{e} \geq 2300
$$

From the relation it is also clear that thermal performance is directly proportional to pipe/tube length. Pipe with large length and smaller diameter in EAPHE system gives high thermal performance [89].

\section{Effect of earth surface conditions}

Earlier it was explained that the temperature of subsoil remains constant at depth of 4 meters and 6 meters which is equal to mean annual earth surface solar temperature [20, 23]. Moreover condition of the earth surface is also responsible for the effective working of the earth pipe heat exchanger system .In their investigation, many researchers depicted the results of various locations for different climate conditions.

Bansal et al. [61] carried out the investigation to analyse the performance of earth pipe heat exchanger for two different climatic conditions (1) In winter season, surface is covered with blackened and glazed surface (2) In summer season, the surface is shaded and wetted to decrease the temperature of soil. Sodhat et al. [90] and Sawhney et al. [91] reported the effect of pipe length under various earth surface condition in three regions (1) hot-dry climate in Jodhpur (Rajasthan) (2) composite climate in Delhi, India and (3) cold-dry climate in Leh. Mihalakakou 
investigated the performance of the EAPHE with arrangement of single and multiple pipes under two surface conditions (a) covered with bare soil (b) covered with soil having short grass. As a result, it was reported that summer season soil with short glass provided best performance while bare soil surface was much helpful for winter season due to its high heating capacity [94].

\section{Impact of other factors.}

Two most important factors were introduced by Singh et al. [110] which included Fan factor and Tunnel factor. Both the factors were responsible for thermal performance of the EAPHE system. Fan factor helps to understand the required size of the fan as per the occupied space requirement while tunnel factor demonstrates the size of tunnel for optimal thermal comfort of the occupied space. Ahmad et al. [87] investigated the influence of the outlet pipe height of the EAPHE on the output of the system which includes different parameters also. In the analysis it was reported that height of outlet had inverse effect on the systems performance. Result shows the influence of outlet pipe height on the thermal performance of the heat exchanger system. As the height of the pipe increases above 0.1 meter the thermal performance of the EAPHE decreases. Hence, negative performance of the system can be minimized by keeping the outlet pipe height below 0.1meter. In recent Mathur et al. [120] studied the issue of space for installing the EAPHE system. For this he made comparative study between the two arrangement of pipe i.e. straight type arrangement and spiral arrangement of pipe using CFD model in transient thermal analysis. The results shows the coefficient of performance of EAPHE, in which the spiral arrangement for summer season was more as compared to the straight pipe arrangement. For straight arrangement in summer season it was evaluated as 4.3 and for spiral arrangement it was 4.48. Whereas straight arrangement in winter season it was evaluated as 5.0 for spiral arrangement it was 5.16. Figure 1 shows the common layout diagram for the straight and spiral tube arrangement.

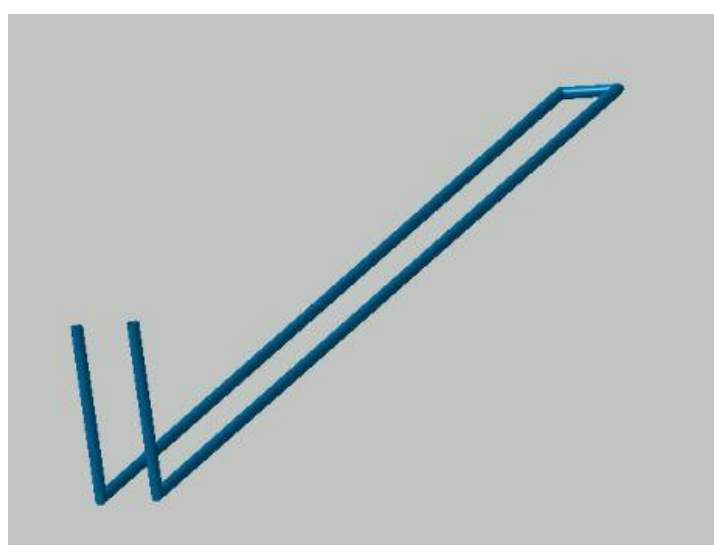

(a)

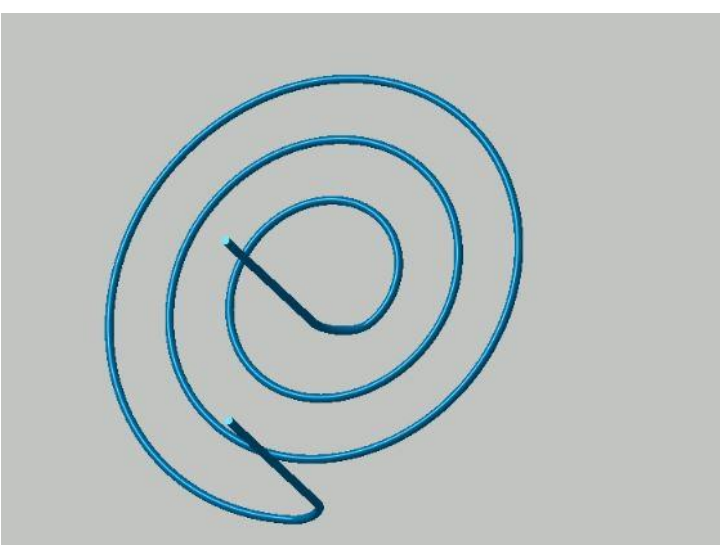

(b)

Figure 1. (a) Schematic diagram for straight pipe EAPHE arrangement. (b) Schematic diagram for spiral pipe EAPHE arrangement.

\section{BASIC GEOMETRY OF EAPHE AND VARIOUS MODELLING APPROACHES.}

In a simplified form, the EAPHE system uses indoor and outdoor air through the buried pipes where the exchange of heat takes place. Under this arrangement, the pipe of a desired size is buried inside the soil, where the temperature remains constant (about 4 meters) and the air passes through it using the blower or blower. In the system, one end acts as an air intake, while the other end is an exit. The entire system decides its performance according to weather conditions. The air is cooled in summer season while in the winter season the air heats up for thermal comfort. Let us assume that due to extraction of heat from the soil variation in temperature near the vicinity of buried pipe does not take place.

The energy balance equation for the width of the pipe (dy) written as:

$$
\mathrm{m} C_{a} \frac{\partial T_{a}}{\partial y} d y=Q b d y
$$

where: 
$\mathrm{Q}=$. Heat transferred quantity per unit area of the tunnel/pipe surface

Amount of heat transferred by convection is expressed as:

$$
Q_{c}=h_{c}\left(T_{s}-T_{a}\right)
$$

where:

$T_{s}=$ Surface temperature of tunnel or pipe

Assumption;

$$
T_{s}>T_{a}
$$

On solving both equation (3) \& (4) and combining them with initial condition

$T_{a}=T_{\text {in }}$ at $\mathrm{y}=0$

The equation will be: $\quad T_{a}(y)=T_{s}-\left(T_{s}-T_{i n} e^{\frac{-h_{c} b y}{m c_{a}}}\right)$

The rise in temperature of pipe expressed in:

$$
\Delta T=\left(T_{s}-T_{i n}\right)\left[1-\exp \left[\frac{-h_{c} b L}{m c_{a}}\right]\right.
$$

where $\mathrm{L}=$ Length of the pipe.

If $T_{\text {in }}>T_{S}$

-ve $\Delta T$ will obtain which indicate cooling of the air.

In case the pipe inner surface is in wet condition, transfer of vapours also take place and can be evaluated as:

$$
m_{w}=h_{d}\left(W_{s}-W\right)
$$

where;

$W_{s}=$ Humidity ratio (at saturation stage of air)

$h_{d}=$ Mass transfer coefficient

The convective heat transfer coefficient of the pipe is :

$$
\frac{\mathrm{h}_{\mathrm{c}}}{\mathrm{h}_{\mathrm{D}}}=\frac{\mathrm{k}}{\mathrm{D}_{\mathrm{m}} \rho_{\mathrm{a}}}\left(\frac{\mathrm{D}_{\mathrm{m}}}{\mathrm{D}}\right)^{\mathrm{c}}
$$

Since

$$
W_{s}-W=\frac{C_{a}}{\zeta}\left(T_{a}-T_{s}\right)
$$

Heat possessed by the water vapour :

$$
Q_{e}=h_{D} C_{a}\left(T_{a}-T_{s}\right)
$$

This adds cooling effect to the tunnel:

$$
Q_{T}=-\left(h_{c}+h_{D} C_{a}\right)\left(T_{a}-T_{s}\right)
$$

Where $C_{a}=(1.005+10884 \mathrm{~W}) \times 10^{3}$ represents the specific heat of water vapour addition of the dry air.

During the investigations many model were proposed [104,87,21,105,79,4,90,92,106,107,108,109] to demonstrate the transient

phenomena of the soil above the buried pipe and the EAPHE system. Mihalakakou et al. [4] evaluated the thermal behaviour of earth surface using numerical model in case of EAPHE. On the other hand Krarti and Krieder also 
investigated analytically to analyse the thermal performance using a model developed by them. During the study assumption was taken that the performance of the system reaches quasi static stage with certain interval of operation.

One dimensional model was developed by Benhammou and Draoui [77] in order to investigate the transient behaviour of EAPHE system. They validated the model against theoretical and experimental approach by Bansal et al.[90] using the approach of computational fluid dynamics under Fluent. Mihalakakou et al. [4] found out the model for both heat and mass transfer simultaneously and also made evaluation of the model for thermal performance due to turbulent flow of the air in it. Niu et al. [59] compared the numerical approach with the experimental data in which two dimensional dynamic heat transfer mechanism was analysed using transient control volume method with the division of soil computing domain into control units along axial and radial direction. In the model by Yang et al. [67] performance of EAPHE was considered by harmonic temperature signal observed from both pipe inlet and the ground surface of proposed model. In whole investigation model was validated using CFD simulation to ensure the accuracy of result obtained experimentally. Figure 2 shows the cross section view of underground pipe used in EAPHE system.

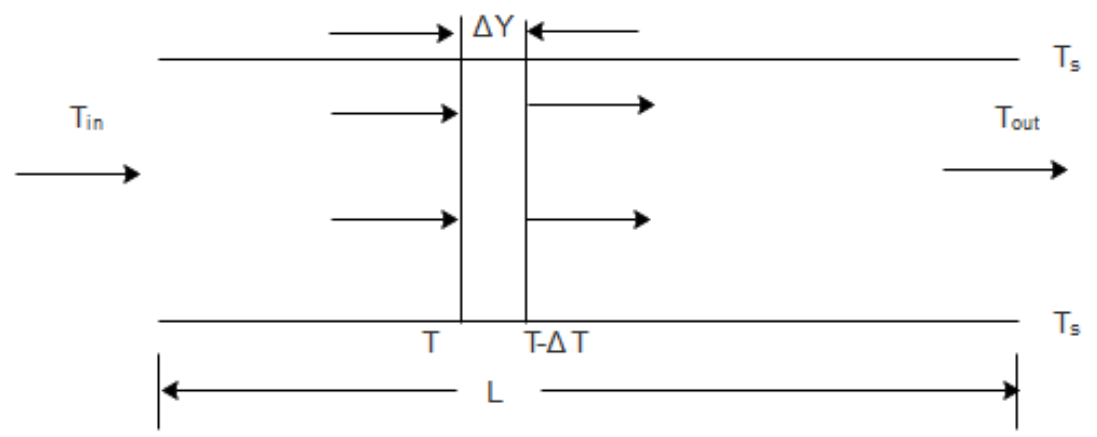

Figure 2. Cross-sectional view of underground pipe.

The model has been developed with different configurations for better EAPHE efficiency. Some of the configurations include: (a) open loop system (b) closed-loop system (c) loop-loop configuration system. In an open loop or ventilated system, EAPHE uses total ambient air to achieve thermal comfort in the occupied space [52] and eventually is exhausted again in the atmosphere. Goswami and Bisnoi demonstrated both the open loop system and the indirect system in which the COP of both systems were compared. In the closed-loop system, the air is continuously recirculated from the pipe / tunnel buried in the occupied space. [5,39] Sawhney et al. has analysed how EAPHE is being recirculated in Ghoshi, India's unconventional research institute for cooling eight of its chambers. In another study, the recirculation system combines with the conventional air conditioning system to analyse the performance (COP) of the system. [95] It can be seen that the performance of the EAPHE system varies significantly according to the following parameters like: (a) pipe diameter (b) pipe length (c) pipe depth (d) soil properties (e) the meteorological condition of the locality. In the partial opening loop configuration, the air blown through the pipe is a mixture of both ambient air and room air in a suitable proportion to the suction point of the pipe to achieve better performance. In some analyses, air conditioning is preconditioned before it is fed into the occupied space. In this process, a conventional vapour compression cycle is used to preheat the air blowing through the buried pipe. Moreover, each arrangement or system had single or multiple ducts such as (a) parallel to one or more layers of pipes and connected to the suction and discharge antenna that were common to all parallel conduits [85] b) Vertical or horizontal comb structure [96] (c) spiral tubular structure [97] for system analysis, various analytical and theoretical models were developed and analysed using different simulation and analysis software (TRANSYS, MATLAB, Energy plus). Different research has been investigated and concluded by several researchers, despite the need to investigate possible means to recover soil temperature for the desired production.

\section{INNOVATIVE DESIGNS OF EAPHE SYSTEM WITH PRACTICAL APPLICATION.}

\section{EAPHE system in ventilation mode}

Investigations have been conducted to increase the thermal comfort of the system with low energy potential. The integration of EAPHE with the ventilation system was another approach that was investigated by Darkwa et.al. [99] where they installed the system in (CSET) at the University of Nottingham. Their study concluded that the integrated system 
has enough energy-saving potential with a higher efficiency of the system where its system reached the COP of approximately 3.2-3.53 for March and July respectively.

\section{Integration of EAPHE system with Solar Chimney}

Various experimental analyses have been carried out for integrated system investigations. The integration of the EAPHE system with the solar chimney was introduced by Maerafet and Haghighi [100]. Figure 3 shows the diagram of the integrated system. Breesch et al. [98] performed comparative analyses in office building between EAPHE system and night mode. In their investigation they reported that the effectiveness of night ventilation is much better as compared to EAPHE system in summer season. Figure 3 shows the day and night operation mode.

The integrated system contains a surface of a glass facing the south wall. The wall was responsible for capturing solar radiation during the day. The EAPHE system consists of parallel pipes, with spacing between them considered only at the penetration depth of the pipe, to change the large amount of heat between the air and the ground. The solar chimney contributes to energy saving for the EAPHE system during the day as air circulation takes place continuously due to the chimney chimney effect. Also, the above investigation concluded that the length of the pipe should be more than 20 meters for effective thermal comfort in the interior. Table 5 shows the pipe length effect on the performance of the EAPHE system. Recently, Niu et al. [93] performed the analysis of the integrated chimney system using the two-dimensional model. The result of the analysis was concluded by comparing the experimental data that was collected from the existing system that was used to develop indoor thermal comfort. Preheating or pre-cooling of the air also consumes energy for its operation [101,118].

Thier and Peuportier [103] investigated the system to preheat/pre-cool the fresh air economically. Hence they utilized EAPHE system in order to consume passive energy of the earth. The system was assumed to be working as heat sink in day time for cooling the indoor.

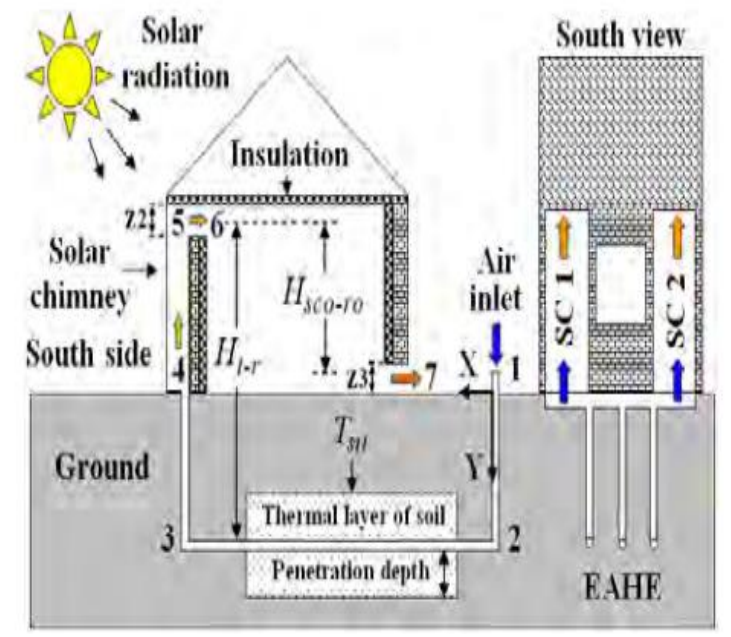

Figure 3. Integrated EAPHE system with solar chimney [121], with permission from Springer Nature.

The next investigation was carried out in the Greater Paris area where installation of the system was carried out in two buildings. Amongst them, a building was used by elders with connected EAPHE system. The EAPHE system consisted of eight 50-meter polyethylene pipeline under the 1.6 meter depth and the second was installed in the tertiary building where the office that supplied EAPHE-supplied air, comprising six long pipes 25 meters buried at a depth of 1.6 meters. Table 8 shows effect of different length of EAPHE system and number of solar chimney on the indoor comfort of building.

\section{EAPHE system assisted by wind tower}

Wind tower EAPHE system was investigated by Benhammou et al. [102] for thermal comfort in dry hot arid region of Algeria. Figure 4 shows the schematic diagram of the system. Table 7 depicts the variation in thermal behaviour of the integrated system with variation in parameters of EAPHE and Wind tower system. 


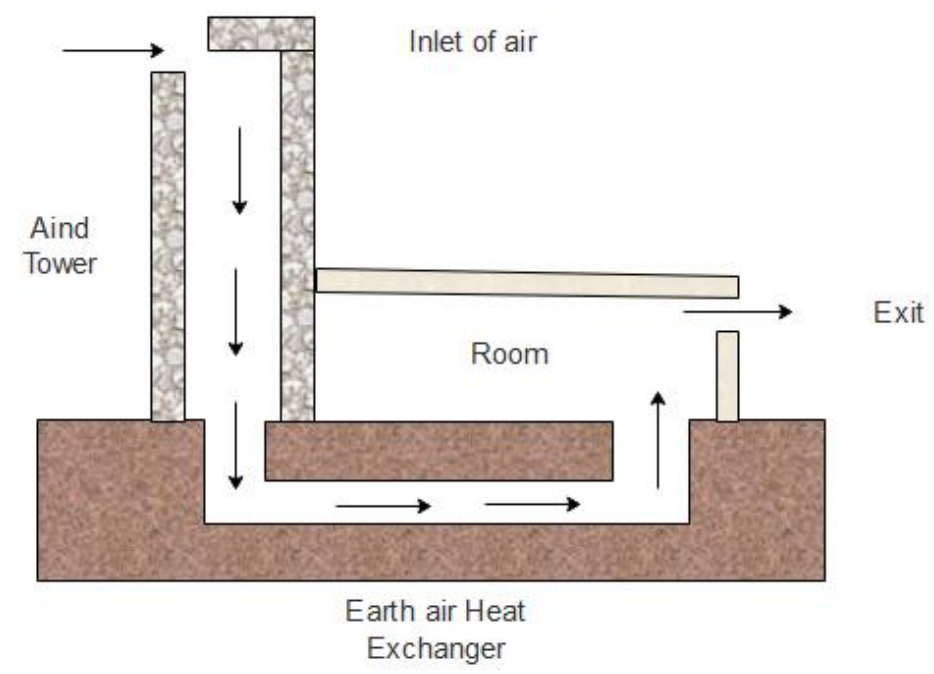

Figure 4. Schematic diagram of wind tower assisted EAPHE system

Table 7. Wind tower and EAPHE system parameter effect on the performance of the system. (I), (II), (III), (IV) [102].

(I)

\begin{tabular}{|l|l|l|}
\hline $\begin{array}{l}\text { Pipe } \\
\text { Diameter } \\
(\mathbf{C m})\end{array}$ & $\begin{array}{l}\text { Air } \\
\text { velocity } \\
(\mathbf{m} / \mathbf{s})\end{array}$ & $\begin{array}{l}\text { Temperature } \\
\left({ }^{0} \mathbf{C}\right)\end{array}$ \\
\hline 1.5 & 1.18438 & 18.4087 \\
\hline 12 & 1.92007 & 16.1635 \\
\hline 25 & 2.56131 & 12.485 \\
\hline 35 & 3.15895 & 9.52044 \\
\hline 45 & 3.66031 & 7.48229 \\
\hline 55 & 4.09628 & 6.0545 \\
\hline 65 & 4.49591 & 4.94823 \\
\hline 75 & 4.78837 & 4.20708 \\
\hline 90 & 5.01362 & 3.67302 \\
\hline 100 & 5.15713 & 3.297 \\
\hline & & \\
\hline
\end{tabular}

(III)

\begin{tabular}{|l|l|l|}
\hline $\begin{array}{l}\text { Tower Height } \\
(\mathrm{m})\end{array}$ & $\begin{array}{l}\text { Air } \\
\text { velocity } \\
(\mathrm{m} / \mathrm{s})\end{array}$ & $\begin{array}{l}\text { Temperature } \\
\left({ }^{\circ} \mathrm{C}\right)\end{array}$ \\
\hline 1 & 2.51073 & 12.5393 \\
\hline 2 & 2.56596 & 12.4567 \\
\hline 3 & 2.6204 & 12.3787 \\
\hline 4 & 2.67147 & 12.306 \\
\hline 5 & 2.72126 & 12.2353 \\
\hline 6 & 2.76529 & 12.1721 \\
\hline 7 & 2.80772 & 12.1119 \\
\hline 8 & 2.84966 & 12.0553 \\
\hline 9 & 2.88953 & 12.0006 \\
\hline 10 & 2.92667 & 11.9492 \\
\hline & & \\
\hline
\end{tabular}

(II)

\begin{tabular}{|r|r|r|}
\hline $\begin{array}{r}\text { Tower cross } \\
\text { section }\left(\mathbf{m}^{\mathbf{2}}\right)\end{array}$ & $\begin{array}{r}\text { Mean } \\
\text { efficiency }\end{array}$ & $\begin{array}{r}\text { Velocity } \\
(\mathbf{m} / \mathbf{s})\end{array}$ \\
\hline 0.2 & 2.54931 & 12.483 \\
\hline 0.3 & 2.56055 & 12.4665 \\
\hline 0.4 & 2.56574 & 12.4575 \\
\hline 0.5 & 2.56758 & 12.4556 \\
\hline 0.6 & 2.56833 & 12.4545 \\
\hline 0.7 & 2.56874 & 12.454 \\
\hline 0.8 & 2.56896 & 12.4537 \\
\hline 0.9 & 2.56907 & 12.4535 \\
\hline 1 & 2.56919 & 12.4533 \\
\hline 0.1 & 2.56922 & 12.4531 \\
\hline 1.2 & 2.56929 & 12.453 \\
\hline
\end{tabular}

(IV)

\begin{tabular}{|l|l|l|}
\hline $\begin{array}{l}\text { Pipe } \\
\text { length } \\
(\mathrm{m})\end{array}$ & $\begin{array}{l}\text { Mean } \\
\text { Efficiency }\end{array}$ & $\begin{array}{l}\text { Daily cooling } \\
\text { potential }(\mathrm{KWh})\end{array}$ \\
\hline 10 & 12.0593 & 11.9354 \\
\hline 20 & 27.2296 & 19.752 \\
\hline 30 & 42.0741 & 24.8427 \\
\hline 40 & 55.0519 & 28.0184 \\
\hline 50 & 65.837 & 29.9061 \\
\hline 60 & 74.5481 & 30.5399 \\
\hline 70 & 81.4222 & 30.6353 \\
\hline 80 & 86.3704 & 30.2604 \\
\hline 90 & 90.4 & 29.6062 \\
\hline 100 & 93.3333 & 28.8021 \\
\hline
\end{tabular}




\section{Utilization of EAPHE system in gas turbine power}

Investigation was done by Barakat et al. [104] in which EAPHE system was coupled with gas power plant. Figure 5 shows EAPHE system coupled with gas turbine.

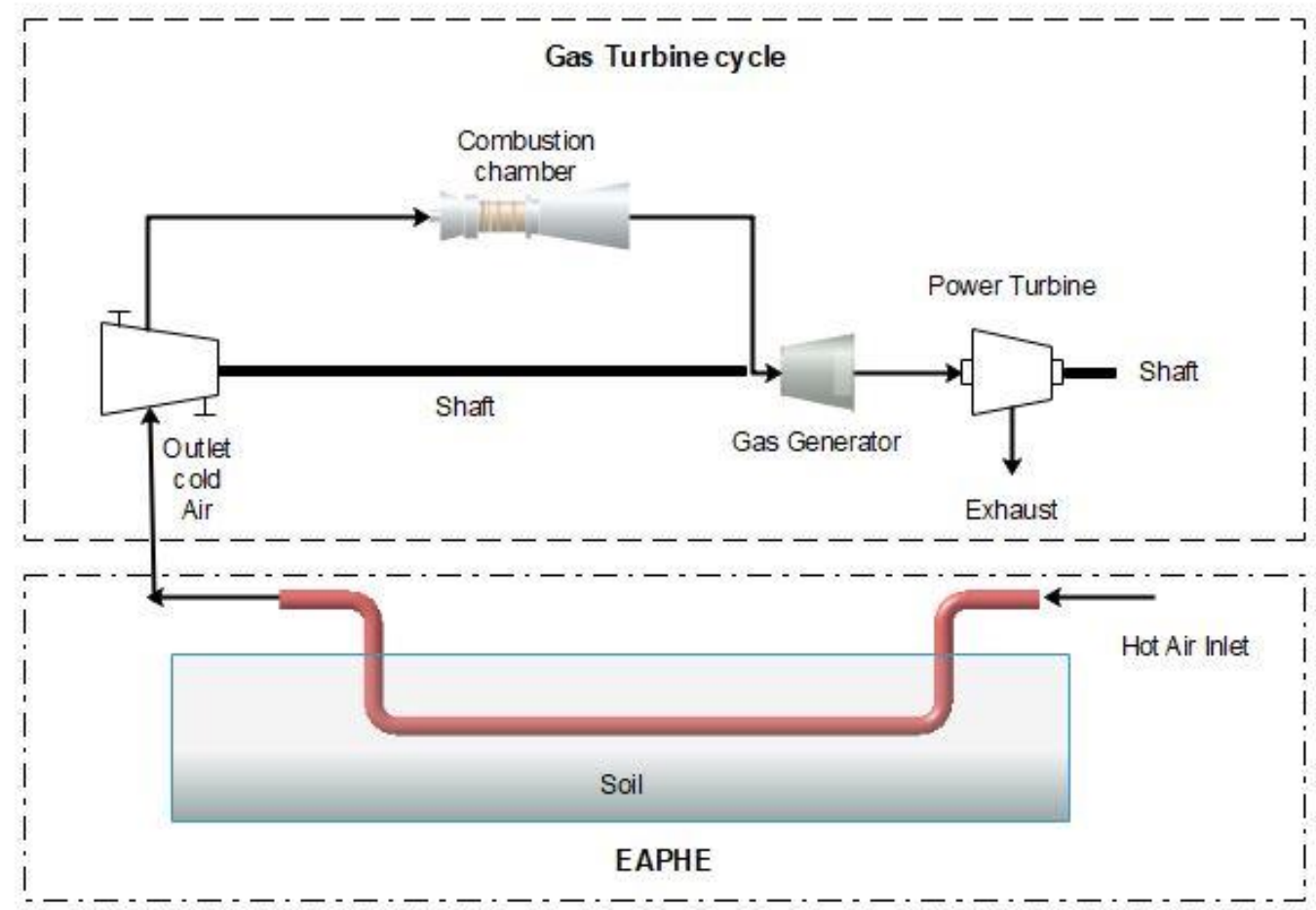

Figure 5. Diagram of gas turbine coupled with EAPHE system.

For analysis they developed a 1-dimensional model of the integrated gas power plant system with EAPHE to evaluate the performance, efficiency and fuel consumption by gas power plant. As a result, it was concluded that the output power was increased by $9 \%$ and thermal efficiency about $4.8 \%$ of gas power plant after the implementation of EAPHE system with it. Thermal efficiency increased by about $4.8 \%$ of gas power plant after the implementation of EAPHE system with it.

Table 8. Effect of length of EAPHE on system performance [100]

\begin{tabular}{|c|c|c|c|c|c|c|c|}
\hline $\begin{array}{l}\text { cooling } \\
\text { demand }(W)\end{array}$ & $\begin{array}{l}\text { Ambient air } \\
\text { temperature } \\
\left({ }^{\circ} \mathrm{C}\right)\end{array}$ & $\begin{array}{l}\text { Solar } \\
\text { radiation } \\
\left(\mathrm{W} / \mathrm{m}^{2}\right)\end{array}$ & $\begin{array}{l}\text { Length } \\
\text { of } \\
\text { EAPHE }\end{array}$ & $\overline{\mathrm{ACH}}$ & $\begin{array}{l}\text { Room } \\
\text { temperature } \\
\left({ }^{\circ} \mathrm{C}\right)\end{array}$ & $\begin{array}{l}\text { No } \\
\text { of } \\
\text { SC }\end{array}$ & $\begin{array}{l}\text { No of } \\
\text { EAPHE }\end{array}$ \\
\hline \multirow[t]{4}{*}{116} & \multirow[t]{4}{*}{40} & \multirow[t]{4}{*}{400} & 15 & 3.47 & 29.68 & 4 & 10 \\
\hline & & & 25 & 6.02 & 29.72 & 3 & 2 \\
\hline & & & 35 & 5.17 & 27.00 & 3 & 2 \\
\hline & & & 45 & 5.79 & 28.61 & 3 & 1 \\
\hline \multirow[t]{4}{*}{116} & \multirow[t]{4}{*}{40} & \multirow[t]{4}{*}{1000} & 15 & 3.47 & 29.87 & 2 & 9 \\
\hline & & & 25 & 6.49 & 28.72 & 2 & 3 \\
\hline & & & 35 & 4.65 & 28.77 & 1 & 1 \\
\hline & & & 45 & 3.56 & 26.33 & 1 & 1 \\
\hline \multirow[t]{4}{*}{800} & \multirow[t]{4}{*}{40} & \multirow[t]{4}{*}{400} & 15 & \multicolumn{4}{|c|}{ Thermal comfort cannot be provided } \\
\hline & & & 25 & 3.14 & 29.00 & 3 & 5 \\
\hline & & & 35 & 4.54 & 29.50 & 3 & 2 \\
\hline & & & 45 & 4.27 & 27.00 & 3 & 2 \\
\hline \multirow[t]{4}{*}{800} & \multirow[t]{4}{*}{40} & \multirow[t]{4}{*}{1000} & 15 & \multicolumn{4}{|c|}{ Thermal comfort cannot be provided } \\
\hline & & & 25 & 3.35 & 29.38 & 2 & 6 \\
\hline & & & 35 & 7.42 & 29.52 & 2 & 3 \\
\hline & & & 45 & 5.59 & 29.26 & 2 & 2 \\
\hline
\end{tabular}




\section{SOIL MODELLING APPROACH IN EAPHE SYSTEM}

In EAPHE, properties of soil play an important role in improving the thermal performance of the system. Among the different properties, the thermal conductivity of the soil contributes the major effect to provide the desired output while leaving the system. Mishra et al. [111] investigated the impact of moisture content on system performance. For analysis, they proposed a system for semi-arid regions in Ajmer (India) with dry and wet soil. System performance was investigated based on system exit temperature. As a result, it was found that the temperature drop was $90 \%$ with a 26-meter pipe length and a moisture content of $15 \%$ and the same temperature drop of $90 \%$ was observed for a $40-$ meter length of the dry soil pipeline. The result concluded that moisture content in the soil must maintain the effectiveness of the EAPHE system. Table 9, 10 shows the system performance based on dry and wet soil along the length of the pipe. In the following approach, Agarwal et al. [112] studied the effect of soil humidity in the basement in the vicinity of the buried pipe. Within EAPHE, researchers have proposed a system to maintain moisture content in the system and dry soil system. The results showed that in the case of dry soil, the system requires a long pipe length for the same performance as wet soil. It was also concluded that the average COP was high for wet soil compared to that of dry soil. Table 9 and 10 show the heat transfer rate and the performance coefficient for soil and wet soil. Recently, Mathur et al. [119] investigated the different ways and its influence on the operation of the EAPHE system with three different soils in three different areas using the CFD transitory analysis. In the three modes, the first mode is taken as a continuous mode with a continuous operation of 12 hours, while the other two modes have a continuous operation of 60 minutes, with a residence time of 20 and 40 minutes. Soils with different thermal properties were taken from Ajmer, Jodhpur and Presles (France) with a thermal conductivity of $0.52,1.00$ and $1.28 \mathrm{Wm}^{-1} \mathrm{~K}^{-1}$ respectively. CFD analysis was performed in different operating modes with three different soils and the EAPHE performance after 12 hours continuous thermal conductivity of $1.28 \mathrm{Wm}^{-1} \mathrm{~K}^{-1}$ was found to be $5.04 \%$, while in the case of low thermal conductivity it was found $1.81 \%$. Performance of the system analysed in both operating conditions i.e. continuous and intermittent. In the research it was concluded that mode of operation greatly affects the thermal performance of EAPHE system because in continuous operation, soil reaches the saturation stage and leads to a deterioration of the thermal performance. While in the case of an intermittent mode the soil has time to accumulate the soil temperature in the neighbourhood, therefore for a lower thermal conductivity it is beneficial to operate intermittently compared to the continuous mode. Table 11 shows efficiency of the wet and dry soil EAPHE systems along the length of pipe with 15 percentage wetness. It reaches at constant value after certain length of the pipe.

Figure 6 average variation in heat transfer rate and COP with dry soil and wet soil at different moisture content wet soil with $15 \%$ moisture shows improved performance. Table 12 shows the air outlet temperature under continuous mode and intermittent mode for three different soil conditions.

Table 9. Daily average heat transfer between pipe surface and soil [112]

\begin{tabular}{|l|r|r|r|}
\hline \multicolumn{3}{|c|}{$\begin{array}{c}\text { Daily average heat trasfer rate between } \\
\text { pipe surface and soil. }\end{array}$} \\
\hline \multirow{4}{*}{ Type of soil } & \multicolumn{3}{|c|}{$\begin{array}{c}\text { Daily average heat } \\
\text { transfer rate through }\end{array}$} \\
& \multicolumn{3}{|c|}{ EATHE pipe surface } \\
\cline { 2 - 4 } & Apr- & May- & Jun- \\
& 17 & 17 & 17 \\
\hline Dry soil & 39.62 & 40.56 & 31.96 \\
\hline $5 \%$ moisture & 47.37 & 46.6 & 36.58 \\
\hline $10 \%$ moisture & 47.54 & 48.52 & 39.15 \\
\hline $15 \%$ moisture & 48.3 & 48.78 & 39.41 \\
\hline $20 \%$ moisture & 48.63 & 50.19 & 39.67 \\
\hline
\end{tabular}

Table 10. Average COP of dry soil and wet soil EAPHE system on daily basis [112]

\begin{tabular}{|l|r|r|r|}
\hline \multicolumn{4}{|c|}{$\begin{array}{c}\text { Average COP of dry and wet EATHE } \\
\text { system on daily basis }\end{array}$} \\
\hline \multirow{4}{*}{ Type of soil } & \multicolumn{3}{|c|}{$\begin{array}{c}\text { Daily average COP of } \\
\text { dry and wet EATHE } \\
\text { system W/m }\end{array}$} \\
\cline { 2 - 4 } & $\begin{array}{r}\text { Apr- } \\
17\end{array}$ & $\begin{array}{r}\text { May- } \\
17\end{array}$ & $\begin{array}{r}\text { Jun- } \\
17\end{array}$ \\
\hline Dry soil & 2.99 & 3.06 & 2.41 \\
\hline $5 \%$ moisture & 3.57 & 3.51 & 2.76 \\
\hline $10 \%$ moisture & 3.58 & 3.66 & 2.95 \\
\hline $15 \%$ moisture & 3.64 & 3.68 & 2.97 \\
\hline $20 \%$ moisture & 3.66 & 3.78 & 2.99 \\
\hline
\end{tabular}




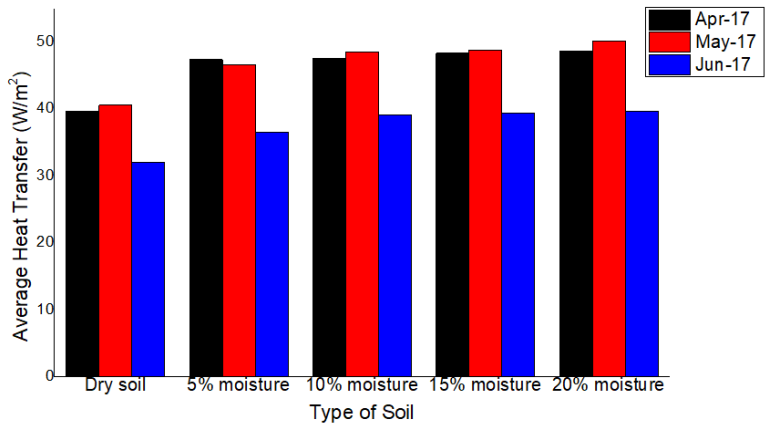

(a)

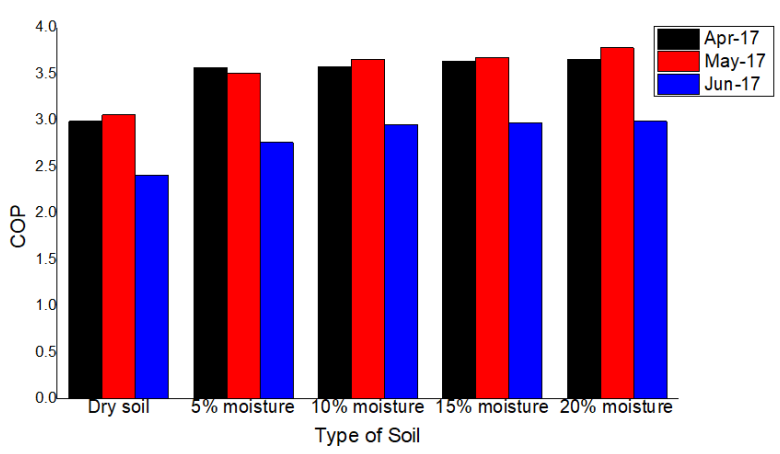

(b)

Figure 6. Variation in performance of the system under dry soil and wet soil; (a) Average heat transfer rate, (b) Average COP [112]

Table 11. Exegetic efficiency of the wet and dry soil EAPHE systems along the pipe length with $15 \%$ wetness. [111]

\begin{tabular}{|r|r|r|}
\hline $\begin{array}{l}\text { Pipe } \\
\text { length } \\
\text { (m) }\end{array}$ & \multicolumn{2}{|c|}{ exotic efficiency } \\
\hline & Dry soil & Wet soil \\
\hline 5 & 52.2732 & 53.1592 \\
\hline 10 & 50.3222 & 51.6512 \\
\hline 20 & 49.2526 & 49.7903 \\
\hline 30 & 49.2432 & 49.4927 \\
\hline 40 & 49.2424 & 49.4597 \\
\hline 60 & 49.3549 & 49.5162 \\
\hline
\end{tabular}

Table 12 (a) Outlet temperature of air under continuous mode (b) outlet temperature of air under intermittent mode for three different soil conditions.

[119] (a)

\begin{tabular}{|l|l|l|l|}
\hline Time (Min) & \multicolumn{3}{|c|}{ Temperature $\left({ }^{\circ} \mathrm{C}\right)$} \\
\hline & Soil 1 & soil 2 & soil 3 \\
\hline 40 & 301.5 & 301 & 301 \\
\hline 80 & 300.2 & 300.15 & 300.1 \\
\hline 120 & 301.8 & 301.15 & 301.1 \\
\hline 160 & 300.3 & 300.16 & 300.16 \\
\hline 200 & 302.1 & 301.25 & 301.2 \\
\hline 240 & 300.4 & 300.16 & 300.16 \\
\hline 280 & 302.2 & 301.35 & 301.3 \\
\hline 320 & 300.45 & 300.17 & 300.17 \\
\hline 360 & 302.4 & 301.45 & 301.4 \\
\hline 400 & 300.5 & 300.18 & 300.18 \\
\hline 440 & 302.5 & 301.55 & 301.5 \\
\hline 480 & 300.55 & 300.185 & 300.185 \\
\hline 520 & 302.55 & 301.65 & 301.6 \\
\hline 560 & 300.57 & 300.19 & 300.19 \\
\hline 600 & 302.6 & 301.68 & 301.64 \\
\hline 640 & 300.6 & 300.195 & 300.195 \\
\hline 680 & 302.7 & 301.7 & 301.6 \\
\hline 720 & 300.6 & 300.2 & 300.2 \\
\hline \multicolumn{4}{|l}{} \\
\hline
\end{tabular}

(b)

\begin{tabular}{|l|l|l|l|}
\hline Time (hr) & \multicolumn{3}{|c|}{ Temperature $\left({ }^{0} \mathrm{C}\right)$} \\
\hline & Soil 1 & soil 2 & soil 3 \\
\hline 1 & 301.5 & 301 & 301 \\
\hline 2 & 301.7 & 301.1 & 301.09 \\
\hline 3 & 301.9 & 301.2 & 301.18 \\
\hline 4 & 301.95 & 301.3 & 301.25 \\
\hline 5 & 302 & 301.4 & 301.35 \\
\hline 6 & 302.2 & 301.5 & 301.45 \\
\hline 7 & 302.4 & 301.6 & 301.47 \\
\hline 8 & 302.6 & 301.7 & 301.5 \\
\hline 9 & 302.8 & 301.8 & 301.55 \\
\hline 10 & 303 & 301.9 & 301.6 \\
\hline 11 & 303.2 & 301.95 & 301.65 \\
\hline 12 & 303.4 & 302 & 301.7 \\
\hline
\end{tabular}

Furthermore investigation was done by Mishra et al. [117] in which 3D transient CFD analysis of EAPHE system was performed for three different soil conditions having a thermal conductivity of $0.52,2.0,4.0 \mathrm{Wm}^{-1} \mathrm{~K}^{-1}$ under hot arid climate of Ajmer. In the analysis, parametric study of the derating factor was analysed on three different soils with different pipe diameter, pipe length and air velocity. The evaluated result concluded that the thermal conductivity of the soil is the main factor which can assign the thermal performance of EAPHE. Graph in Figure 7 shows that derating factor of the soil with lower thermal conductivity is more in comparison to the soil with high thermal conductivity under transient operating condition with respect to pipe length which is between 0.2-0.3 after twenty four hours of operation of thermal conductivity of soil $4.0 \mathrm{Wm}^{-1} \mathrm{~K}^{-1}$ as compared to approx. 0.4 for 
thermal conductivity of soil $2.0 \mathrm{Wm}^{-1} \mathrm{~K}^{-1}$. Figure 7 shows derating factors of the system under different pipe length and soil thermal conductivity.
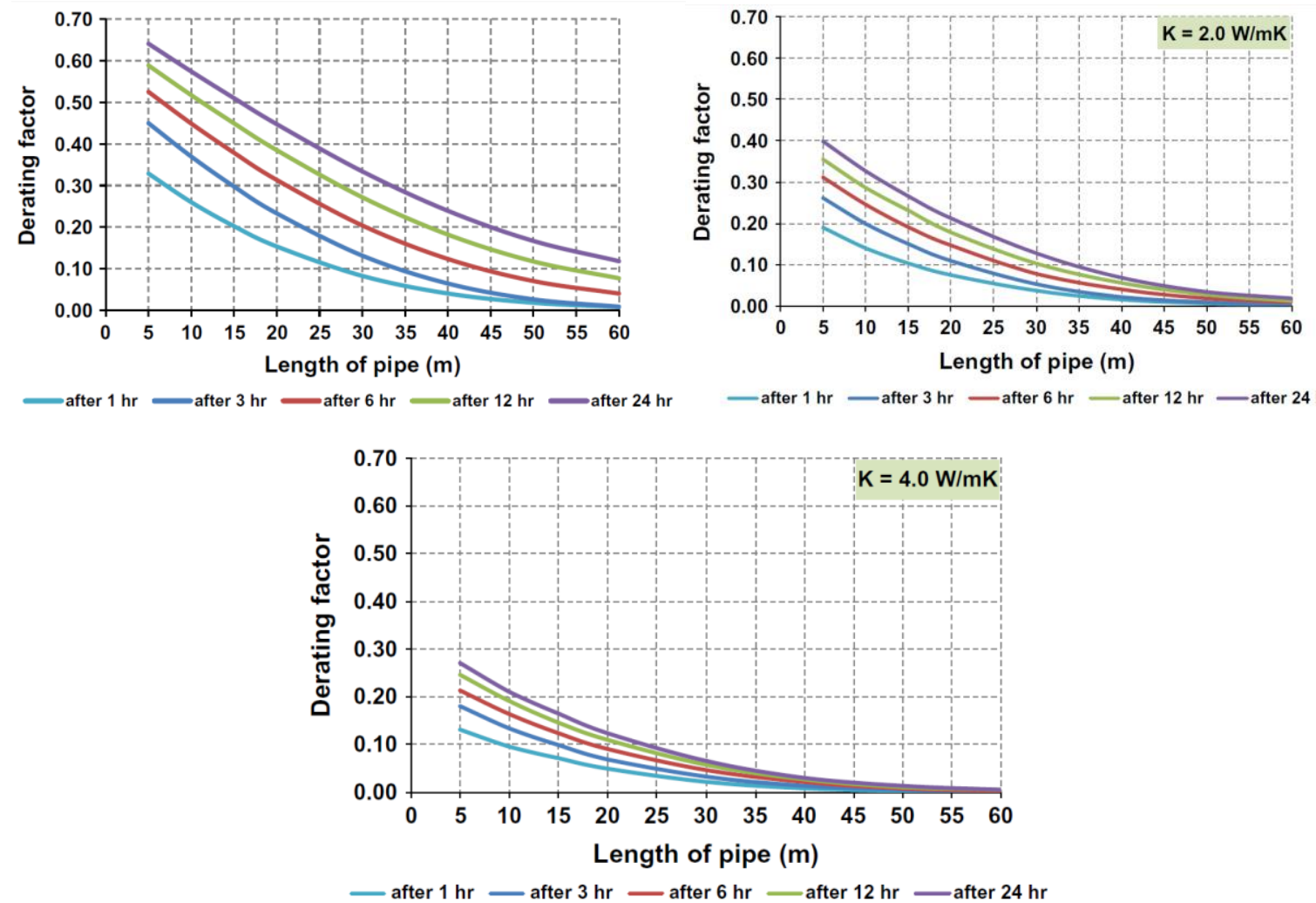

Figure 7. Derating factor as per the thermal conductivity of the soil. [117], with permission from Elsevier.

\section{DISCUSSION}

In the review, the EAPHE system was explained as a powerful option for indoor thermal comfort in the building area. Many researchers have been interested in developing the various models to optimize the efficiency of the system, as well as to significantly use passive energy. The overall analysis has concluded the best operational condition of the EAPHE system through different experimental and analytical models. In experiments, most researchers completed the soil depth between 0.5 meters and 4 meters for an optimal outcome / result. The study shows that EAPHE is the best way to use passive energy and reduce greenhouse gas emissions through the conventional air conditioning system. To optimize the efficiency and effectiveness of the EAPHE system it is necessary to treat the soil so as to increase the thermal conductivity of the soil. For this, different techniques of shading, soil soaking, use of short grass, etc. were applied. Analytical analysis utilized different dimensional and three-dimensional models and analysis using similar software (ANSYS, Energyplus, Fluent, Matlab, etc.).

Table 13 below summarizes the EAPHE comparative study based on design parameters including pipe length, pipe diameter, pipe quantity, pipe depth, pipe material, pipe distance. All of the factors mentioned above are responsible for the efficient operation of the system to ensure the interior thermal comfort.

\section{CONCLUSION AND RECOMMENDATION}

The earth air pipe heat exchanger system becomes one of the most widely used as passive energy source to provide thermal comfort in the occupied space. It is the best way to use geothermal energy to reduce the consumption of conventional resources for heating / cooling indoor spaces. The general study of various experimental or analytical research using different bi-dimensional or three-dimensional models has helped to understand the approach of technology under different circumstances. The whole article demonstrated all the factors responsible for the effectiveness of the EAPHE system and also demonstrated the advantages and disadvantages of different system parameters to enhance the thermal potential of the system.

The study concluded that the depth of the buried pipe should vary between 0.5 and 4 meters. Increasing air speed reduces the thermal performance of the system; therefore, it is necessary to operate the system with an optimal air speed. 
Performance of EAPHE system depends upon thermal properties of soil above the buried pipe. After continuous operation, performance of EAPHE deteriorated due to thermal saturation of soil, so it is recommended to adopt such methods that maintain moisture content of soil to retain the thermal properties.

Performance of the EAPHE system is independent of the pipe material hence use of cheap PVC pipes are advised. Long pipes with small diameter gives better performance compare to the larger diameter.

Output pipe height is also an important factor affecting the thermal efficiency of the system; it is recommended to ensure an optimum outlet height for a better output.

To optimize the current system, other systems are coupled with EAPHE, such as the solar basket, photovoltaic cells, the wind turbine, etc. and which are significantly demonstrated in this article.

After extensive study of literature related to EAPHE system, it is advised that study should be carried out with different layout design of the pipe and cross section of pipe to enhance the performance of the system. Further modelling of the soil above the buried pipe should be carried out to enhance the effective working duration of the system. 
Journal of Thermal Engineering, Review Article, Vol. 6, No. 5, pp. 651-676, October, 2020

Table:13 Comparative analysis of EAPHE based on different parameter

\begin{tabular}{|c|c|c|c|c|c|c|c|c|c|c|c|c|}
\hline Author & $\begin{array}{l}\text { Length } \\
\text { of pipe } \\
\text { (meter) }\end{array}$ & $\begin{array}{l}\text { Diameter } \\
\text { of pipe } \\
\text { (meter) }\end{array}$ & No. of pipes & $\begin{array}{c}\text { Spacing } \\
\text { between } \\
\text { pipes } \\
\text { (meter) }\end{array}$ & $\begin{array}{l}\text { Soil thermal } \\
\text { conductivity }\end{array}$ & $\begin{array}{l}\text { Burial } \\
\text { depth } \\
\text { (meter) }\end{array}$ & $\begin{array}{c}\text { Air } \\
\text { velocity } \\
(\mathbf{m} / \mathbf{s e c})\end{array}$ & $\begin{array}{c}\text { Pipe } \\
\text { material }\end{array}$ & $\begin{array}{c}\text { Operating } \\
\text { Equipment }\end{array}$ & Climate & Major finding (conclusion) & Reference \\
\hline $\begin{array}{l}\text { D. Belatrache } \\
\text { et al. } 2017\end{array}$ & 45 & 0.08 & 1 & - & & 5 & 1 & PVC & Blower & $\begin{array}{l}\text { Hot arid } \\
\text { climate }\end{array}$ & $\begin{array}{l}\text { The difference in temperature between } \\
\text { ambient and EAPHE outlet obtained } \\
\text { about } 20.7^{\circ} \mathrm{C} \text { in July month. The } \\
\text { temperature reduces continuously until } \\
\text { the air temperature and subsoil } \\
\text { temperature became equal. }\end{array}$ & {$[80]$} \\
\hline $\begin{array}{l}\text { A.A Serageldin } \\
\text { et al. } 2016\end{array}$ & 5.5 & 0.0508 & $\begin{array}{l}4 \text { (serpentine } \\
\text { arrangement) }\end{array}$ & 0.2 & & 2 & $1-.39$ & PVC & Blower & - & $\begin{array}{l}\text { Temperature drop- } 20.4^{\circ} \mathrm{C}-18.7^{\circ} \mathrm{C} \text {. } \\
\text { Diameter of pipe: } 0.0508 \text { to } 0.0762 \\
\text { meter } \\
\text { Change in spacing between the pipe } \\
\text { effects insignificantly from } 0.2 \text { meter } \\
\text { to } 0.5 \text { meter. }\end{array}$ & [75] \\
\hline $\begin{array}{l}\text { M. Khabbaza et } \\
\text { al. } 2016\end{array}$ & 72 & 0.15 & 3 & 0.14 & & 2.85 & $3.8-5$ & PVC & Blower & $\begin{array}{l}\text { Hot semi } \\
\text { arid climate }\end{array}$ & $\begin{array}{l}\text { The system was capable of proving cool } \\
\text { air of temperature } 25^{\circ} \mathrm{C} \text { with } 40 \% \text { of } \\
\text { humidity content during the ambient } \\
\text { temperature of } 40^{\circ} \mathrm{C} \text {. }\end{array}$ & [113] \\
\hline $\begin{array}{l}\text { S. Uddin et al. } \\
2016\end{array}$ & 14.33 & 0.0381 & 6 & 0.305 & & 2.44 & - & PVC & Blower & - & $\begin{array}{l}\text { Winter season-average rise in } \\
\text { temperature }\left(9{ }^{\circ} \mathrm{C}\right) \text { relative humidity } \\
\text { decreased by } 28 \% \\
\text { Summer season-drop in temperature } \\
\left(6^{\circ} \mathrm{C}\right) \text {, relative humidity decrease by } \\
10 \%\end{array}$ & [140] \\
\hline $\begin{array}{l}\text { S. Barakat et al. } \\
2016\end{array}$ & 85 & 0.32 & 853 & - & & 5 & 4.5 & $\mathrm{PVC}$ & Blower & - & $\begin{array}{l}\text { The output and the efficiency of gas } \\
\text { power plant was increased by } 9 \% \text { and } \\
4.8 \% \text {.Coupling the EAPHE system } \\
\text { increased production by } 12991 \mathrm{MW} \\
\text { with revenue of } 1.655 \mathrm{x}\end{array}$ & [104] \\
\hline $\begin{array}{l}\text { Sanjeev Jakhar } \\
\text { etal } 2016\end{array}$ & 60 & 0.1 & 1 & - & & 3.7 & $2.5-12$ & PVC & Blower & $\begin{array}{l}\text { Hot semi } \\
\text { arid climate }\end{array}$ & $\begin{array}{l}\text { For an optimal output the burial depth of } \\
\text { the pipe was estimated } 3.7 \text { meter and } \\
\text { length } 34 \text { meter. Thermal performance } \\
\text { decreases with increase in velocity of } \\
\text { air. }\end{array}$ & [114] \\
\hline
\end{tabular}


Journal of Thermal Engineering, Review Article, Vol. 6, No. 5, pp. 651-676, October, 2020

\begin{tabular}{|c|c|c|c|c|c|c|c|c|c|c|c|c|}
\hline $\begin{array}{l}\text { M.Benhammou } \\
\text { and B. Draoui } \\
2015\end{array}$ & 23.42 & 0.15 & - & - & & - & 2 & PVC & - & $\begin{array}{l}\text { Arid and } \\
\text { hot climate }\end{array}$ & $\begin{array}{l}\text { The thermal performance of the EAPHE } \\
\text { system much affected by different } \\
\text { parameters such as diameter of pipe, } \\
\text { velocity of air and operating duration in } \\
\text { transient condition as compared to } \\
\text { steady state. }\end{array}$ & [79] \\
\hline $\begin{array}{l}\text { Anuj Mathur et } \\
\text { al. (2015) }\end{array}$ & 40 & 0.1 & - & - & $0.52,1.00,1.28$ & - & - & PVC & blower & $\begin{array}{l}\text { Hot arid } \\
\text { climate }\end{array}$ & $\begin{array}{l}\text { The performance of the EAPHE system } \\
\text { vary as per the thermal conductive of } \\
\text { the soil for thermal conductivity } 1.28 \mathrm{~W} \\
\text { the thermal performance of the system } \\
\text { was } 5.04 \% \text { while for thermal } \\
\text { conductivity } 0.52 \text { W thermal } \\
\text { performance was } 1.81 \% \text {. }\end{array}$ & [120] \\
\hline $\begin{array}{l}\text { S.F Ahmad et } \\
\text { al. } 2015\end{array}$ & 6 & 0.021 & 20 & 0.02 & & $0.73-1.09$ & - & PVC & & - & $\begin{array}{l}\text { With horizontal pipe-temperature } \\
\text { arrangement- decreased by } 1.05^{\circ} \mathrm{C} \text {. } \\
\text { Vertical pipe arrangement- temperature } \\
\text { reduced by } 1.82^{\circ} \mathrm{C}\end{array}$ & [96] \\
\hline $\begin{array}{l}\text { Fuxin Niu et } \\
\text { al..2015 }\end{array}$ & 57 & 0.45 & - & - & & 3 & - & Steel & - & - & $\begin{array}{l}\text { Subsoil near pipe-High temperature } \\
\text { Subsoil away from pipe vicinity- low } \\
\text { temperature }\end{array}$ & [93] \\
\hline $\begin{array}{l}\text { Nadia Saifi et } \\
\text { al.. } 2015\end{array}$ & 60 & 0.11 & $\begin{array}{l}4 \quad \text { (serpentine } \\
\text { layout ) }\end{array}$ & 2 & & 3 & 4.54 & - & Blower & $\begin{array}{l}\text { Arid and } \\
\text { semi-arid } \\
\text { climate }\end{array}$ & $\begin{array}{l}\text { Increased the thermal comfort by } \\
\text { reducing the temperature from } 30^{\circ} \mathrm{C}- \\
22^{\circ} \mathrm{C} \text { as well reduced the energy } \\
\text { potential from } 15 \text { watt }-8 \text { watt. }\end{array}$ & [42] \\
\hline $\begin{array}{l}\text { Fuxin Niu et al. } \\
2015\end{array}$ & 57 & 0.45 & - & - & & 3 & - & Steel & & & $\begin{array}{l}\text { The material effectively reduces the } \\
\text { temperature of the air for small air } \\
\text { velocity. It was observed that } \\
\text { temperature of the material is directly } \\
\text { proportional to the output of the system. }\end{array}$ & [115] \\
\hline $\begin{array}{l}\text { M. } \\
\text { Benhammou et } \\
\text { al..2015 }\end{array}$ & 60 & 0.3 & - & - & & 2.13 & - & - & & - & $\begin{array}{l}\text { The analysis implies that the thermal } \\
\text { potential of the system was varies with } \\
\text { respect to diameter of the pipe and } \\
\text { length of the pipe too. }\end{array}$ & [102] \\
\hline $\begin{array}{l}\text { Aliyah N.Z. } \\
\text { Sanusi etal } \\
2013\end{array}$ & 30 & 0.076 & . & - & & $0.5,1.0,1.5$ & 5.6 & Polyethylene & Blower & $\begin{array}{l}\text { Hot and } \\
\text { humid } \\
\text { climate }\end{array}$ & $\begin{array}{l}\text { Effective reduction in temperature } \\
\text { observed for } 1 \text { meter buried pipe } \\
\text { during hot, dry and humid climate. }\end{array}$ & [116] \\
\hline $\begin{array}{l}\text { Rohit Mishra } \\
\text { et al. } 2012\end{array}$ & 60 & 0.3 & - & - & $0.52,2.0,4.0$ & 2.13 & 1.5 & - & Blower & $\begin{array}{l}\text { Hot climate } \\
\text { of Ajmer }\end{array}$ & $\begin{array}{l}\text { Derating factor increase with decrease } \\
\text { in thermal conductivity of soil. For } \\
\text { thermal conductivity } 4 \mathrm{~W} \text { the derating } \\
\text { factor was analysed } 2-3 \text { after twenty } \\
\text { four hours of working while for } \\
\text { thermal conductivity } 2 \mathrm{~W}\end{array}$ & [117] \\
\hline
\end{tabular}


Journal of Thermal Engineering, Review Article, Vol. 6, No. 5, pp. 651-676, October, 2020

\begin{tabular}{|c|c|c|c|c|c|c|c|c|c|c|c|}
\hline $\begin{array}{l}\text { J. Darkwa et } \\
\text { al.. } 2011\end{array}$ & 50 & 0.4 & 0.6 & - & $1.5-3$ & - & - & - & - & $\begin{array}{l}\text { The EAPHE system attained } 3.2 \\
\text { coefficient of performance various heat } \\
\text { losses to surrounding and } 62 \% \text { of } \\
\text { heating load in the month of march. }\end{array}$ & [99] \\
\hline $\begin{array}{l}\text { Vikas Bansal et } \\
\text { al.. } 2010\end{array}$ & 23.42 & 0.15 & - & - & 2.7 & $2,3.2,4.5$ & PVC & - & - & $\begin{array}{l}\text { Cooling capacity of the system } \\
\text { decreased with rise in air velocity while } \\
\text { temperature increased with increase in } \\
\text { velocity of air from } 8.0^{\circ} \mathrm{C} \text { to } 12^{\circ} \mathrm{C} \text { with } \\
\text { variation of air velocity from } 2 \text { to } \\
5 \mathrm{~m} / \mathrm{sec} \text {. }\end{array}$ & {$[78,105]$} \\
\hline $\begin{array}{l}\text { Stphane } \\
\text { and Thiers } \\
\text { Peupotier. } \\
2008\end{array}$ & 50,25 & - & 8.6 & - & 1.6 & - & PVC & Blower & - & $\begin{array}{l}\text { Thermal comfort by EAPHE system can } \\
\text { be achieved by coupling other passives } \\
\text { energy sources(Solar, ventilation roof, } \\
\text { thermal mass). }\end{array}$ & [103] \\
\hline $\begin{array}{l}\text { N.M Thanu et } \\
\text { al. } 2001\end{array}$ & 76.5 & $(0.6 x 0.8)$ & 2 & - & 4 & 6.7 & Brick Plaster & Blower & Composite & $\begin{array}{l}\text { As the air passed through the EAPHE } \\
\text { system its temperature, relative } \\
\text { humidity and humidity ratio were } \\
\text { reduced. }\end{array}$ & {$[37]$} \\
\hline M.Bojie 1999 & 50 & 0.15 & - & $0.4,0.3$ & 1.5 & & steel, PVC & - & - & $\begin{array}{l}\text { The heat exchange for summer was } 1.3 \\
\text { times higher than winter season. } \\
\text { Thermal conductivity of the soil directly } \\
\text { influence the value while spacing } \\
\text { between pipe did not effect the } \\
\text { performance. }\end{array}$ & [77] \\
\hline
\end{tabular}




\section{REFERENCES}

[1] Introduction to national rating system:GRIHA Manual.

[2] Nejat P, Jomehzadeh F, Taheri MM, Gohari M, Majid MZA. A global review of energy consumption, \{CO2\} emissions and policy in the residential sector (with an overview of the top ten $\{\mathrm{CO} 2\}$ emitting countries). Renew Sustain Energy Rev2015;43:843-62.

[3] Jacovides C, Mihalakakou G, Santamouris M, Lewis J. On the ground temperature profile for passive cooling applications in buildings. Sol Energy 1996;57(3):167-75.

[4] Mihalakakou G, Santamouris M, Asimakopoulos D. Modelling the thermal performance of earth-to-air heat exchangers. Sol Energy 1994;53(3):301-5.

[5] Sawhney R, Buddhi D, Thanu N. An experimental study of summer performance of a recirculation type underground air pipe air conditioning system. Build Environ 1999;34:189-96.

[6] Vaz J, Sattler MA, dos Santos ED, Isoldi LA. Experimental and numerical analysis of an earthair heat exchanger. Energy Build 2011;43(9):247682

[7] Jayashankar BC, Sawhney RL, Sodha MS. Effect of different surface treatments of the surrounding earth on thermal performance of earth- integrated buildings. Int JEnergy Res 1989;13:605-19.

[8] Givoni B, Katz L. Earth temperatures and underground buildings. Energy Build 1985;8(1):15-25.

[9] Omer AM. Ground-source heat pumps systems and applications. Renew Sustain Energy Rev 2008;12(2):344-71.

[10] Esen H, Inalli M, Esen M. Numerical and experimental analysis of a horizontal ground-coupled heat pump system. Build Environ 2007;42(3):1126-34.

[11] Givoni B. Earth-integrated buildingsan overview. Archit Sci Rev1981;24(2):42-53,

[12] Deshmukh MK, Sodha MS, Sawhney RL. Effect of depth of sinking on thermal performance of partially underground building. Int J Energy Res 1991;15(5):391-403, 〈http://dx.doi.org/10.1002/er.4440150506〉.

[13] Esen H, Esen M, Ozsolak O. Modelling and experimental performance analysis of solar-assisted ground source heat pump system. J Exp Theor Artif Intell 2017;29(1):1-17,

[14] Lucia U, Simonetti M, Chiesa G, Grisolia G. Ground-source pump system for heating and cooling: review and thermodynamic approach. Renew Sustain Energy Rev 2017;70:867-74.

[15] Inalli M, Esen H. Experimental thermal performance evaluation of a horizontal ground-source heat pump system. Appl Therm Eng 2004;24(1415):2219-2232.

[16] Wu W, You T, Wang B, Shi W, Li X. Simulation of a combined heating, cooling and domestic hot water system based on ground source absorption heat pump. Appl Energy 2014;126:113-22.

[17] Balbay A, Esen M. Experimental investigation of using ground source heat pump system for snow melting on pavements and bridge decks. Sci Res Essay 2010;5(24):3955-66.

[18] Balbay A, Esen M. Temperature distributions in pavement and bridge slabs heated by using vertical ground-source heat pump systems. Acta Sci-Technol 2013;35(4):677-85.

[19] Esen H, Inalli M, Esen M. A techno-economic comparison of ground-coupled and air-coupled heat pump system for space cooling. Build Environ 2007;42(5):1955-65.

[20] Khatry AK, Sodha MS, Malik MAS. Periodic variation of ground temperature with depth. Sol Energy 1978;20:4257.

[21] Wu H, Wang S, Zhu D. Modelling and evaluation of cooling capacity of earthairpipe systems. Energy Convers Manag 2007;48:1462-71.

[22] Ozgener L. A review on the experimental and analytical analysis of earth to air heat exchanger (eahe) systems in turkey. Renew Sustain Energy Rev 2011;15:4483-90.

[23] Trilok Singh Bisoniya PB, Kumar Anil. Experimental and analytical studies of earthair heat exchanger (eahe) systems in india: a review. Renew Sustain Energy Rev 2013;19:238-46.

[24] Clara Peretti MDCRZ, Zarrella Angelo. The design and environmental evaluation of earth-to-air heat exchangers(eahe).a literature review. Renew Sustain Energy Rev 2013;28:107-16.

[25] Kaushal M. Geothermal cooling/heating using ground heat exchanger for various experimental and analytical studies: comprehensive review. Energy Build 2017;139:634-52.

[26] Bayareh M. and Nourbakhsh A., Numerical simulation and analysis of heat transfer for different geometries of corrugated tubes in a double pipe heat exchanger. Journal of thermal engineering 2019;5(4); 293-301.

[27] Keklikcioglu O., Dagdevir T and Ozceyhan V. A CFD based thermo-hydraulic performance analysis in a tube fitted with stepped conical nozzle turbulators. Journal of thermal engineering 2016;2(5);913-920.

[28] Hourmanesh M, Ray H, Elmer DB, Earth air heat exchanger system, In: Prowler D, ed., Proc. 2nd National Passive Solar Conference (March 16-19, 1978)Philadelphia, PA. Newark, DE: American Section of ISES.

[29] Thoburn W. Performance of earth-air tunnel system, Private communication.

[30] Sodha M, Sharma A, Singh S, Bansal N, Kumar A. Evaluation of an earth air tunnel system for cooling/heating of a hospital complex. Build Environ1985;20(2):115-22.

[31] Bansal NK, Sodha MS. An earth-air tunnel system for cooling buildings. Tunn Undergr Space Technol 1986;1(2):17782. 
[32] Akridge J. Investigation of passive cooling techniques for hot humid climates, Research report, College of Architecture, Georgia Institute of Technology, Atlanta, Georgia.

[33] Bansal N, Sodha MS, Bharadwaj SS. Performance of earth-air tunnels. Energy Res 1983;7:333.

[34] Mihalakakou G, Santamouris M, Asimakopoulos D. On the cooling potential of earth to air heat exchangers. Energy Convers Manag 1994;35(5):395-402.

[35] Zhang Q, Ishihara O, Hayashi T. Development of residence with solar heating earth cooling, and air circulation. ASHRAE Trans 1994:333-41.

[36] Ishihara O, Zhang Q. Cooling effects of earth tubes on dwellings. In: Proceedings of the 1992 ASME/JSES/KSES international solar energy conference.

[37] Thanu N, Sawhney R, Khare R, Buddhi D. An experimental study of the thermal performance of an earth-air-pipe system in single pass mode. Sol Energy 2001;71(6):353-64.

[38] Kumar R, Ramesh S, Kaushik S. Performance evaluation and energy conservation potential of earthairtunnel system coupled with non-air-conditioned building. Build Environ 2003;38:807-13.

[39] Chel A, Tiwari GN. Performance evaluation and life cycle cost analysis of earth to air heat exchanger integrated with adobe building for new delhi composite climate.Energy Build 2009;41:56-66.

[40] Al-Ajmi F, Loveday D, Hanby V. The cooling potential of earth air heat exchangers for domestic building in a desert climate. Build Environ 2006;41:235-44.

[41] Bojic M, Trifunovic N, Papadakis G, Kytitsis S. Numerical simulation, technical and economic evaluation of air-toearth heat exchanger coupled to a building. Energy 1997;22:1151-8.

[42] Saifi N, Settou N, Dokkar A. Modeling and parametric studies for thermal performance of an earth to air heat exchanger in south east algeria. In: IREC2015The Sixth International Renewable Energy Congress, 2015, pp. 1-6.

[43] Wang H, Qi C, Wang E, Zhao J. A case study of underground thermal storage in a solar-ground coupled heat pump system for residential buildings. Renew Energy 2009;34:307-14.

[44] Popiel C, Wojtkowiak J, Biernacka B. Measurements of temperature distribution in ground. Exp Therm Fluid Sci 2001;25:301-9.

[45] Ghosal M, Tiwari G, Srivastava N, Sodha M. Thermal modelling and experimental validation of ground temperature distribution in greenhouse. Int J Energy Res 2004;28:45-63.

[46] Florides G, Kalogirou S. Ground heat exchangers-a review of systems, models and applications. Renew Energy 2007;32:2461-78.

[47] Asghar AH, Sharma AK, Singh SP. Effect of different earth surface treatments on sub-soil temperature. Int J Energy Res 1990;14:911-24.

[48] Mihalakakou G, Santamouris M, Lewis J, Asimakopoulos D. On the application of the energy equation to predict ground temperature profiles. Sol Energy 1997;60:181-90.

[49] Ozgener, Onder \& Ozgener, Leyla \& Tester, Jefferson. (2013). A practical approach to predict soil temperature variations for geothermal (ground) heat exchangers applications. International Journal of Heat and Mass Transfer. 62. 473-480. 10.1016/j.ijheatmasstransfer.2013.03.031.

[50] Kusuda T, Achenbach P. Earth temperature and thermal diffusivity on at selected stations in the united stales. ASHRAE Trans 1965;71:61-75.

[51] Kusuda T, Bean W, Annual variation of temperature field and heat transfer under heated ground surface, slab-on grade floor heat loss calculation, Building Science Services 156,

[52] Labs K, Ground cooling. In: J. Cook (Ed.), Passive Cooling, MIT Press: Cambridge, MA; 1989. p. 145-196.

[53] Bharadwaj S, Bansal N. Temperature distribution inside ground for various surface conditions. Build Environ 1981;16(3):183-92.

[54] Mihalakakou G, Santamouris M, Lewis J, Asimakopoulos D. On the application of the energy equation to predict ground temperature profiles. Sol Energy 1997;60:181-90.

[55] Derbel HBJ, Kanoun O. Investigation of the ground thermal potential in tunisia focused towards heating and cooling applications. Appl Therm Eng 2010;30:1091-100.

[56] Givoni B, Katz L. Earth temperatures and underground buildings. Energy Build 1985;8(1):15-25.

[57] Sodha MS, Bansal NK, Seth AK. Variance of the ground temperature distribution. Appl Energy 1981;8:245-54.

[58] Baggs S. Remote prediction of ground temperature in australian soils and mapping its distribution. Sol Energy 1983;30:351-66.

[59] Krarti M, Lopez-Alonzo C, Claridge D, Kreider J. Analytical model to predict annual soil surface temperature variation. J Sol Energy Eng 1995;117:91-9.

[60] Ghosal M, Tiwari G, Srivastava N, Sodha M. Thermal modelling and experimental validation of ground temperature distribution in greenhouse. Int J Energy Res 2004;28:45-63.

[61] Bansal N, Sodha MS, Bharadwaj SS. Performance of earth-air tunnels. Energy Res 1983;7:333.

[62] Sodha M, Bansal N, Kumar A, Bansal P, Malik M. Solar passive building: science and design, 1st edn. Oxford: Pergamon Press; 1986.

[63] de la Flor FS, Domnguez SA. Modelling microclimate in urban environments and assessing its influence on the performance of surrounding buildings. Energy Build 2004;36:403-13. 
[64] Wang H, Qi C, Wang E, Zhao J. A case study of underground thermal storage in a solar-ground coupled heat pump system for residential buildings. Renew Energy 2009;34:307-14.

[65] Khedari J, Permchart W, Pratinthong N, Thepa S, Hirunlabh J. Field study using the ground as a heat sink for the condensing unit of an air conditioner in thailand. Energy 2001;26:797-810.

[66] Givoni B. Options and applications of passive cooling. Energy Build 1984;7:297-300.

[67] Givoni B. Cooled soil as a cooling source for buildings. Sol Energy 2007;81:316-28.

[68] Nassar Y, ElNoaman A, Abutaima A, Yousif S, Salem A. Evaluation of the underground soil thermal storage properties in libya. Renew Energy 2006;31:593-8.

[69] Sodha M, Sharma A, Singh S, Bansal N, Kumar A. Evaluation of an earth air tunnel system for cooling/heating of a hospital complex. Build Environ 1985;20(2):115-22.

[70] Mathur A, Surana AK, Verma P, Mathur S, Agrawal G, Mathur J. Investigation of soil thermal saturation and recovery under intermittent and continuous operation of eathe. Energy Build 2015;109:291-303.

[71] Mihalakakou G, Santamouris M, Asimakopoulos D. On the cooling potential of earth to air heat exchangers. Energy Convers Manag 1994;35(5):395-402.

[72] Mihalakakou G, Lewis J, Santamouris M. The influence of different ground covers on the heating potential of earthto-air heat exchangers. Renew Energy 1996;7(1):33-46.

[73] Kumar R, Ramesh S, Kaushik S. Performance evaluation and energy conservation potential of earthairtunnel system coupled with non-air-conditioned building. Build Environ 2003;38:807-13.

[74] Kabashnikov V, Danilevskii L, Nekrasov V, Vityaz I. Analytical and numerical investigation of the characteristics of a soil heat exchanger for ventilation systems.Int J Heat Mass Transf 2002;45:2407-18.

[75] Serageldin AA, Abdelrahman AK, Ookawara S. Earth-air heat exchanger thermal performance in egyptian conditions: experimental results, mathematical model, and computational fluid dynamics simulation. Energy Convers Manag 2016;122:25-38.

[76] Santamouris M, Mihalakakou G, Balaras C, Lewis J, Vallindras M, Argiriou A.Energy conservation in greenhouses with buried pipes. Energy 1996;21:353-60.

[77] Bojic M, Papadakis G, Kytitsis S. Energy from a two-pipe, earth-to-air heat exchanger. Energy 1999;24:519-23.

[78] Bansal V, Misra R, Agrawal GD, Mathur J. Performance analysis of earthpipeair heat exchanger for winter heating. Energy Build 2009;41:1151-4.

[79] Benhammou M, Draoui B. Parametric study on thermal performance of earth-to air heat exchanger used for cooling of buildings. Renew Sustain Energy Rev 2015;44:348-55.

[80] Belatrache D, Bentouba S, Bourouis M. Numerical analysis of earth air heat exchangers at operating conditions in arid climates. Int. J. Hydrog. Energy 2017;42(13):8898-904.

[81] Badescu V. Simple and accurate model for the ground heat exchanger of a passive house. Renew Energy 2007;32:84555.

[82] Lee KH, Strand RK. The cooling and heating potential of an earth tube system in buildings. Energy Build 2008;40:48694.

[83] Wu H, Wang S, Zhu D. Modelling and evaluation of cooling capacity of earth air pipe systems. Energy Convers Manag 2007;48:1462-71.

[84] Sodha MS, Mahajan U, Sawhney RL. Thermal performance of a parallel earth air pipes system. Int J Energy Res 1994;18:437-77.

[85] Yoon G, Tanaka H, Okumiya M. Study on the design procedure for a multi-cool/heat tube system. Sol Energy 2009;83:1415-24.

[86] Mihalakakou G, Lewis J, Santamouris M. On the heating potential of buried pipes techniques-application in ireland. Energy Build 1996;24:19-25.

[87] Ahmed S, Amanullah M, Khan M, Rasul M, Hassan N. Parametric study on thermal performance of horizontal earth pipe cooling system in summer. Energy Convers Manag 2016;114:324-37.

[88] Sodha MS, Sawhney RL, Jayashankar BC, Sharma AK. Effect of different earth surface treatments on the thermal performance of a room coupled to an earth-air tunnel. Int J Energy Res 1990;14:337-54.

[89] Paepe MD, Janssen M. Thermo-hydraulic design of earthair heat exchangers. Energy Build 2003;35:389-97.

[90] Sodha MS, Buddhi D, Sawhney RL. Thermal performance of underground air pipe: different earth surface treatments. Energy Convers Manag 1991;31(1):95-104.

[91] Sawhney R, Mahatan U. Heating and cooling potential of an underground air-pipe system. Int J Energy Res 1994;18:509-24.

[92] Bansal V, Misra R, Agrawal GD, Mathur J. Performance analysis of earth pipe air heat exchanger for summer cooling. Energy Build 2010;42(5):645-8.

[93] Niu F, Yu Y, Yu D, Li H. Investigation on soil thermal saturation and recovery of an earth to air heat exchanger under different operation strategies. Appl Therm Eng 2015;77:90-100.

[94] Yang D, Guo Y, Zhang J. Evaluation of the thermal performance of an earth-to-air heat exchanger (eahe) in a harmonic thermal environment. Energy Convers Manag 2016;109:184-194 
[95] Goswami D, lieslamlou S. Performance analysis of closed loop climate control system using underground air tunnel. J Sol Energy Eng 1990;112:76-81.

[96] Ahmed S, Khan M, Amanullah M, Rasul M, Hassan N. Performance assessment of earth pipe cooling system for low energy buildings in a subtropical climate. Energy Convers Manag 2015;106:815-25.

[97] Mathur A, Priyam , Mathur S, Agrawal G, Mathur J. Comparative study of straight and spiral earth air tunnel heat exchanger system operated in cooling and heating modes. Renew Energy 2017;108:474-87.

[98] Breesch H, Bossaer A, Janssens A. Passive cooling in a low-energy office building.Sol Energy 2005;79:682-96.

[99] Darkwa J, Kokogiannakis G, Magadzire C, Yuan K. Theoretical and practical evaluation of an earth-tube (e-tube) ventilation system. Energy Build 2011;43:728-36.

[100] Maerefat M, Haghighi A. Passive cooling of buildings by using integrated earth to air heat exchanger and solar chimney. Renew Energy 2010;35:2316-24.

[101] Li H, Yu Y, Niu F, Shafik M, Chen B. Performance of a coupled cooling system with earth-to-air heat exchanger and solar chimney. Renew Energy 2014;62:468-77.

[102] Benhammou M, Draoui B, Zerrouki M, Marif Y. Performance analysis of an earth to-air heat exchanger assisted by a wind tower for passive cooling of buildings in arid and hot climate. Energy Convers Manag 2015;91:1-11.

[103] Thiers S, Peuportier B. Thermal and environmental assessment of a passive building equipped with an earth-to-air heat exchanger in france. Sol Energy 2008;82:820-31.[133] Boji'c M. Optimization of heating and cooling of building by employing refuse and renewable energy. Renew Energy 2000;20:453-65.

[104] Barakat S, Ramzy A, Hamed A, Emam SE. Enhancement of gas turbine power output using earth to air heat exchanger (eahe) cooling system. Energy Convers Manag 2016;111:137-46.

[105] Bansal V, Misra R, Agrawal GD, Mathur J. Performance analysis of earthpipeair heat exchanger for summer cooling. Energy Build 2010;42:645-8.

[106] Bojic M, Trifunovic N, Papadakis G, Kytitsis S. Numerical simulation, technical and economic evaluation of air-toearth heat exchanger coupled to a building. Energy 1997;22:1151-8.

[107] Su H, Liu X-B, Ji L, Mu J-Y. A numerical model of a deeply buried air-earth-tunnel heat exchanger. Energy Build 2012;48:233-9.

[108] Gan G. Simulation of dynamic interactions of the earth air heat exchanger with soil and atmosphere for preheating of ventilation air. Appl Energy 2015;158:118-32.

[109] Gan G. Dynamic interactions between the ground heat exchanger and environments in earth air tunnel ventilation of buildings. Energy Build 2014;85:12-22.

[110] Singh S. Optimization of earth air tunnel system for space cooling. Energy Convers Manag 1994;35(8):721-5.

[111] Rohit Misra , Sanjeev Jakhar, Kamal Kumar Agrawal, Shailendra Sharma, Doraj Kamal Jamuwa , Manoj S. Soni , Ghanshyam Das Agrawal. Field investigations to determine the thermal performance of earth air tunnel heat exchanger with dry and wet soil: Energy and exergetic analysis. Energy \& Buildings 171 (2018) 107-115

[112] Kamal Kumar Agrawal, Rohit Misra, Tejpal Yadav, Ghanshyam Das Agrawal , Doraj Kamal Jamuwa. Experimental study to investigate the effect of water impregnation on thermal performance of earth air tunnel heat exchanger for summer cooling in hot and arid climate.

[113] Khabbaz M, Benhamou B, Limam K, Hollmuller P, Hamdi H, Bennouna A.Experimental and numerical study of an earth-to-air heat exchanger for air cooling in a residential building in hot semi-arid climate. Energy Build2016;125:109-21.

[114] Jakhar S, Misra R, Soni M, Gakkhar N. Parametric simulation and experimental analysis of earth air heat exchanger with solar air heating duct. Eng Sci Technol, Int J 2016;19(2):1059-66.

[115] Niu F, Yu Y, Yu D, Li H. Heat and mass transfer performance analysis and cooling capacity prediction of earth to air heat exchanger. Appl Energy2015;137:211-21.

[116] Aliyah NI, Sanusi a NZ. Passive ground cooling system for low energy buildings in malaysia (hot and humid climates). Renew Energy 2013;49:193-6.

[117] Misra R, Bansal V, Agrawal GD, Mathur J, Aseri T. CFD analysis based parametric study of derating factor for earth air tunnel heat exchanger Applied.Energy 2013;103(266-277).

[118] Amin Haghighi Poshtiri, Neda Gilani, Farshad zamiri.Feasibility study on using solar chimney and earth-to-air heat exchanger for natural heating of buildings. World renewable energy congress 2011- Sweden.

[119] Anuj Mathur, Ayushman Srivastavab, G.D. Agrawala, Sanjay Mathura,Jyotirmay Mathura. CFD analysis of EATHE system under transient conditions forintermittent operation. Energy and Buildings 87 (2015) 37-44. www.elsevier.com/locate/enbuild.

[120] Anuj Mathur, Priyam a, Sanjay Mathur , *, G.D. Agrawal , Jyotirmay Mathur. Comparative study of straight and spiral earth air tunnel heat exchanger system operated in cooling and heating modes.

[121] Verma M.K., Bansal V., Rana K.B. (2019) Study on Performance Analysis of Earth-Air-Pipe Heat Exchanger as Passive Cooling and Heating System. Advances in Fluid and Thermal Engineering. Lecture Notes in Mechanical Engineering. Springer, Singapore. https://doi.org/10.1007/978-981-13-6416-7_77 